\title{
A City of Promenades
}

\author{
By Carolyn Aguilar-Dubose* \& Maite García-Vedrenne ${ }^{ \pm}$
}

\begin{abstract}
Studying old maps showing the transformation of Mexico City can unveil possible footprints of historic facilities and utilities that have disappeared in the process of urban modernization. The objective of this exercise is to uncover the location of old structures of Pre-Hispanic and Colonial Mexico City as a basis for creating a new footprint of urban memory and identity. A city of promenades proposes the remembrance and use of public space, such as the recuperation of lost cultural and geographic landscapes. It takes the routes and paths, the aqueducts, the roads, the moats, the ramparts, the gates of the historic city and its connections to other villages, which now conform this great metropolitan area and it revives them in order to bring communities together. Inhabitants experience a sense of belonging to a meaningful place, while looking back to the past of a growing city. These paths will serve as initiators of projects and actions which will improve patterns of use and sense of identity, offering landmarks, establishing linear parks as connectors of different scales of existing parks and, through modern design, creating a rediscovered footprint of monuments, landscapes and infrastructures long gone. This proposal is an integral project for the Mexico City Metropolitan Area. It begins at the neighbourhood level and forms part of an urban park system; connecting the surrounding natural landscapes and woodlands, the urban parks, sports clubs, neighbourhood parks, squares, bridges, central reservations, sidewalks, tree and flower beds, chapels, rights of way, unused railways, roads, avenues, greenhouses, agricultural trails, cemeteries, brooks and waterways, ravines, canals, terraces, balconies, cloisters and convent patios, archeological sites and unbuilt urban block cores. The city of paths and strolls, of boulevards, of old roads to haciendas and convents, of dikes, gateways, old custom house gates, water fountains and springs, canals, causeways, watermills and aqueducts is an academic exercise with students and teachers to find a meaningful representation of the layers of history that builds a city and creates identity.
\end{abstract}

\section{Introduction}

This teaching-learning exercise has been practiced during two school terms in the Undergraduate Architecture Programme at Universidad Iberoamericana, Mexico City. The overall objective of the syllabus is to generate a conversation between students and their awareness of the open space of cities. The course is Landscape Design Studio, and the proposed syllabus is non-conventional in the sense that it does not concentrate on the technique of design, but rather on the 'ideas' and 'ethos' behind parks, gardens and urban open space and their contribution to improving the image, resiliency, health, justice and identity of neighbourhoods, especially if they are connected to form a system.

${ }^{*}$ Professor, Iberoamericana University, Mexico.

${ }^{ \pm}$Research Assistant, Iberoamericana University, Mexico. 
The framework for the syllabus derives its inspiration from the landscape work of French Forestry Engineer Jean-Claude Nicolas Forestier, who proposed linking different park typologies to form park systems. To complement, fiveyears' research has been carried out with students and research assistants towards a method of building park systems for cities.

The first approach is understanding Nature as a historical concept; understanding open space design in different time periods; how parks were a path towards democratizing open space; and how green systems benefit the urban environment.

\section{Pedagogic Approach and Methodology}

The teaching experience of this course has drawn a learning curve that dictates the scale of exercises that can be administered throughout a term (one 18week semester), in order to achieve the desired results with the students. The following is a road map to this teaching-learning activity, demonstrating the different exercises, explaining the objectives pursued and showing examples of the results.

\section{"Education as a Promenade"}

"Landscapes are defined by paths. When people inhabit a place, they cut across it on clear roads, bodies of water, or swaths of the earth beaten down by people and other creatures. Such paths of movements define roads, villages, and cities."1

Design education can also be thought as a path. The proposed pedagogic approach is based on the belief that learning occurs when students are actively involved in a process of constructing meaning and knowledge. In this path, an Action Verb has been assigned to each milestone of the promenade. This process is a loop that goes from a personal introspective search to looking outward (see Figure 1).

1. E. Lupton, Design is Storytelling (New York: Cooper Hewitt, Smithsonian Design Museum, 2017), 117. 


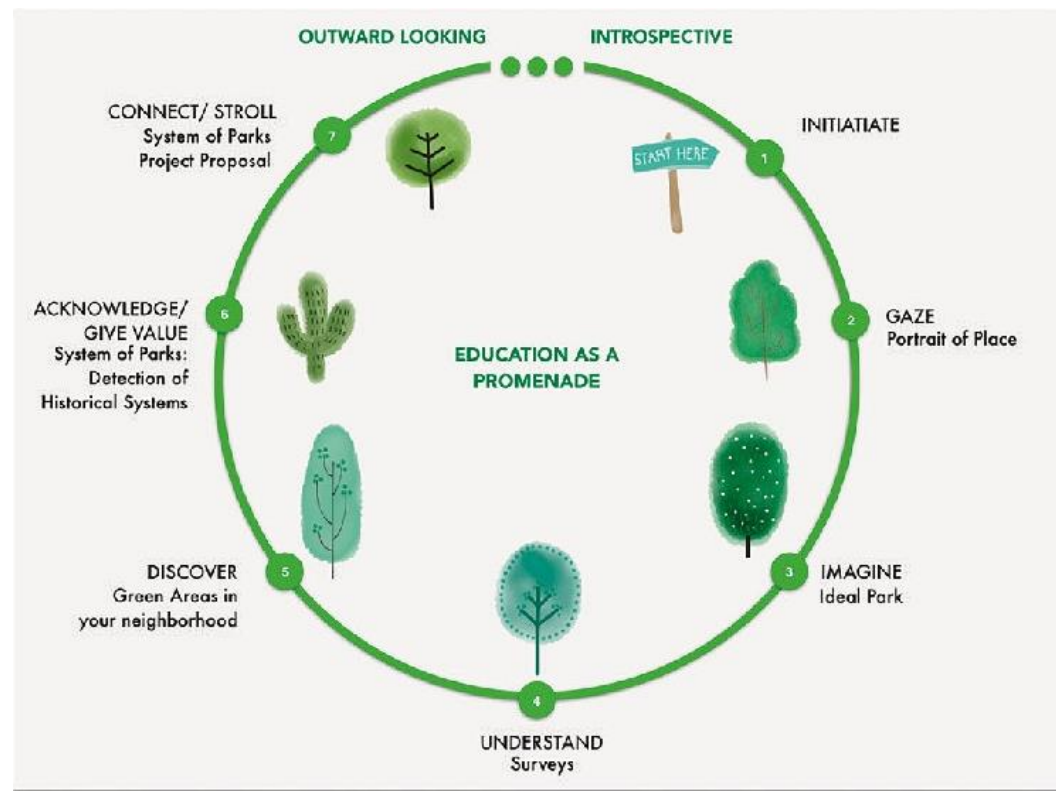

Figure 1. Education as a Promenade

Source: Designed by Maite García-Vedrenne showing the pedagogic approach.

"The Starting Point of All Achievement is Desire"

The syllabus of the course carries with it a distinct intention to learn about landscape 'constructively', as a series of layers that involve comprehending the importance of historical footprints, of urban open space and how the role of personal experience and awareness plays in achieving successful parks for people. The ultimate goal is to build a park system, after having confronted different design scales. The workshop will be Mexico City.

"The Process of Learning about Designing Public Open Space”

Initiate

The first idea to understand is to look at Nature as a historic concept that has accumulated different meaning and significance in Western culture through time. In Antiquity, Nature was sacred, embodied in a feminine figure, and organically connected to humankind. In the Middle Ages, Nature was God's Will on Earth. In the Renaissance, under the mercantilist shroud, the Earth was considered feminine, and so, controlled by her passions, to be subjugated and exploited by man, in a scientific reductionist view, as an object. In the Industrial Era, Nature is an inexhaustible source of wealth and resources to be exploited globally for the benefit of humankind. In contemporary thought, humanity should reinvent its relationship with Nature in which the biosphere is a continuous sheath of life 
covering the face of the Earth. Humans are only a part of this interlinked web. They are stewards, nonetheless, with the responsibility to care for and sustain life. ${ }^{2}$

After reviewing the historicity of the concept of Nature, students begin to understand that it is a component of the nascent urban park of the 19th Century, as a legacy of the private garden, the fruitful countryside and the cherished regional geographic landscape. The private garden is addressed from the point of view of its design (Egyptian, Greco-Roman, Medieval, Islamic, Italian Renaissance, French Baroque, English Style, Romantic, Eclectic, Contemporary, Abstract, PostAbstract) to understand the different aesthetic intentions and ideas.

From the $18^{\text {th }}$ Century examples, students view the transformation of the private garden and hunting grounds into public parks and the design and construction of the public parks of the $19^{\text {th }}$ Century. They also discover the ethos of designing cities since the $17^{\text {th }}$ Century, with an urban form that includes a park system, through a sequence of vegetated squares, avenues with ample tree-lined sidewalks or central medians, and green open space for recreational activities and public services.

Some of the examples covered and reviewed by students contain the intentions of using green open space (parks, squares, tree-lined boulevards) as a planning strategy from the $17^{\text {th }}$ to the $21^{\text {st }}$ Century, when connecting parks and other forms of green space has become a resiliency and sustainability strategy. Here are a few of these examples in chronological order:

1660 - Paris and the demolition of its defensive walls transformed into boulevards and tree-lined promenades, during the reign of Louis $\mathrm{XIV}^{3}$ (see Figure 2). This action prompted a trend of building ample treed parkways in Europe and later in America, becoming potential 'connectors' between green open space.

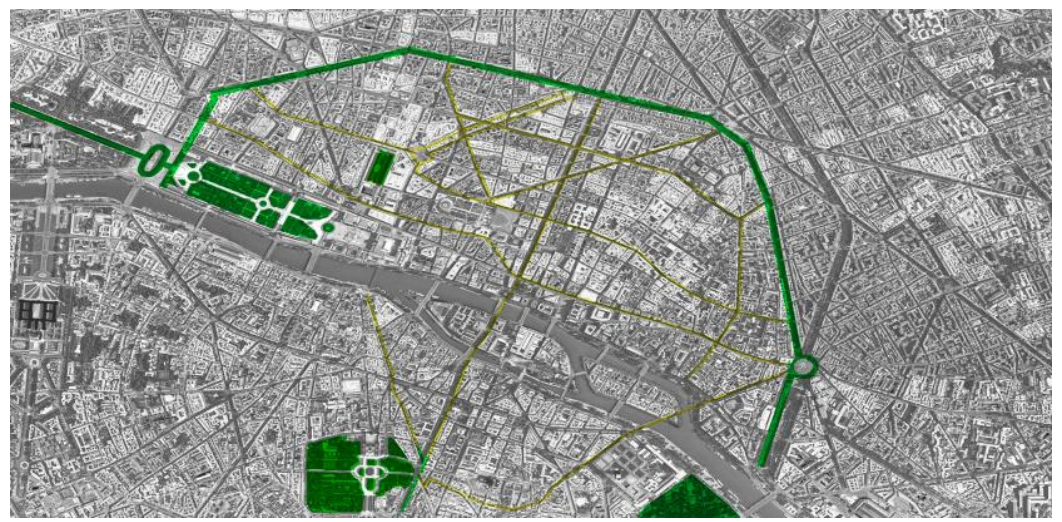

Figure 2. Paris, France. Footprint of the 1660 Boulevards

Source: Adapted from GOOGLE EARTH 2019.

2. C. Aguilar-Dubose, El Parque Urbano: Entre Naturaleza y Democracia. (Ciudad de México: Universidad Iberoamericana, 2020). [En revisión para su publicación].

3. D. P. Jordan, Transforming Paris: The Life and Labors of Baron Haussmann. (New York: The Free Press, Simon and Schuster, Inc., 1995), 29. 
1667 - London and the fire of 1666 meriting its rebuilding with the opening of landscaped squares ${ }^{4}$ (see Figure 3). Housing developers soon understood the market value of townhouses surrounding these parks, and the benefit to the neighbourhood as a whole.

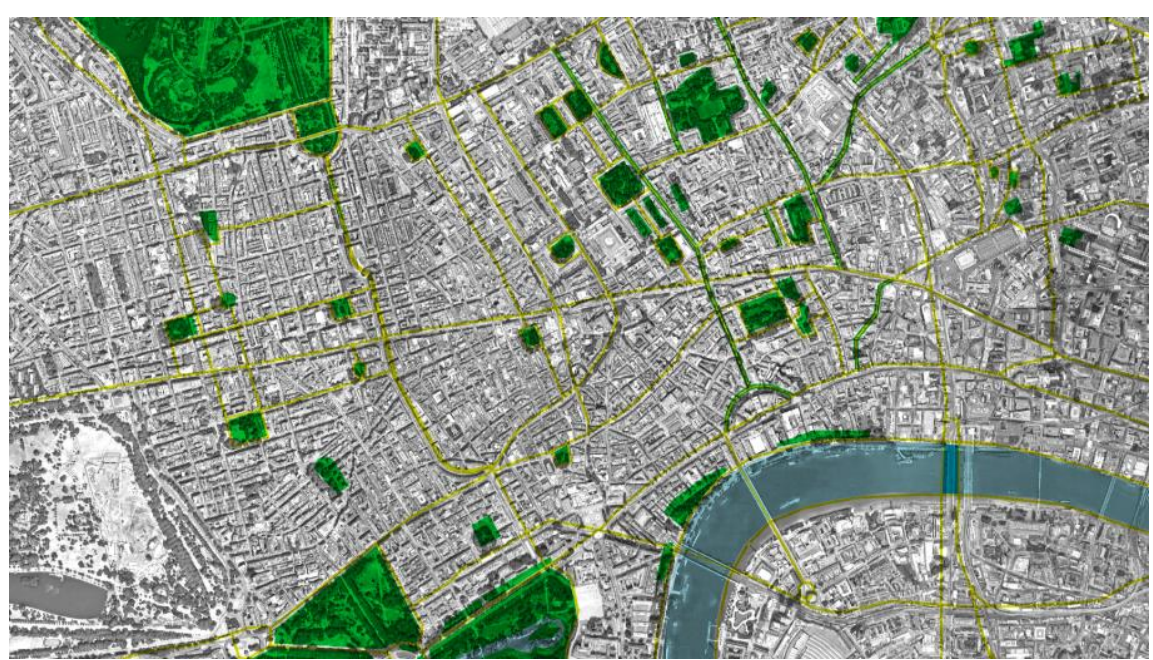

Figure 3. London, UK. Footprint of the Building of Squares Started in 1667 Source: Adapted from Google Earth 2019.

1733 - James Oglethorp builds the city of Savannah, Georgia, ${ }^{5}$ based on a grid of cellular units of 12 blocks that shared a central green square (see Figure 4). Not only was this a control device for planned growth, but also fostered the building o fan identifiable park for each unit. Traffic boulevards with wide central treed medians did not disturb the intimacy of the neighbourhoods.

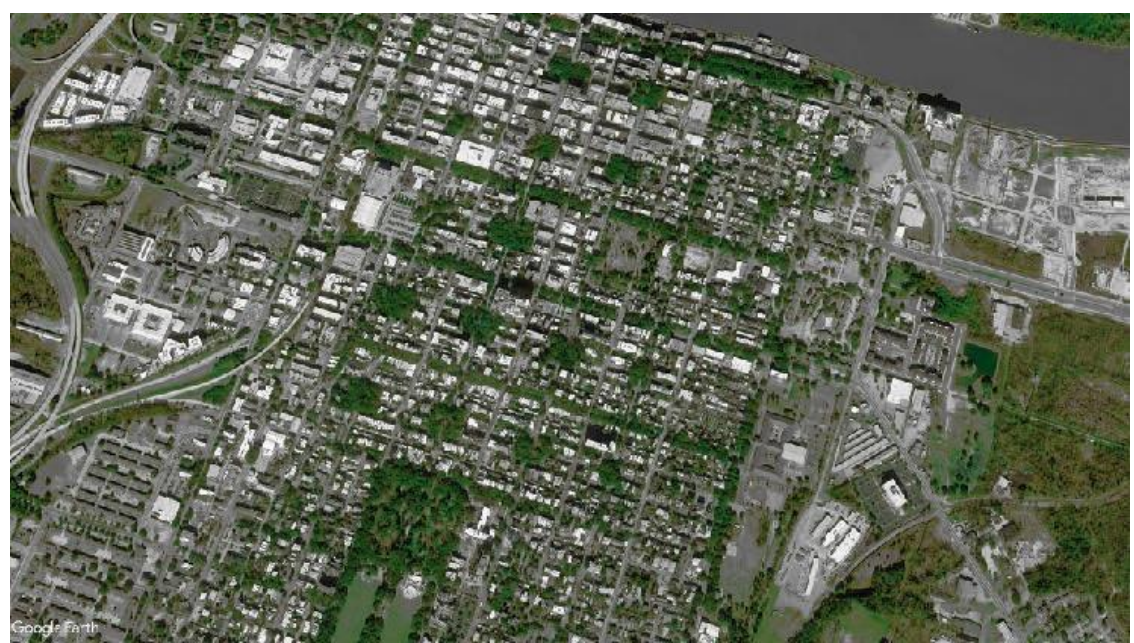

Figure 4. Savannah, Georgia, USA. Footprint, of the Sequence of the Pattern of Squares from 1733

Source: Adapted from Google Earth 2019.

4. A. E. J. Morris, History of Urban Form Before the Industrial Revolution (London: George Godwin Limited, 1979), 261-263.

5. E. N. Bacon, Design of Cities. (New York: Penguin Books, 1976), 220. 
1810 - John Nash designs and builds the connection between St. James' Park and Regent's Park through the layout of the new Regent Street and Portland Place $^{6}$ (see Figure 5). The design idea of connecting two major city parks with an urban thoroughfare stimulated comercial and social traffic, connectivity, increased land use values and an organising structure for $19^{\text {th }}$ Century London.

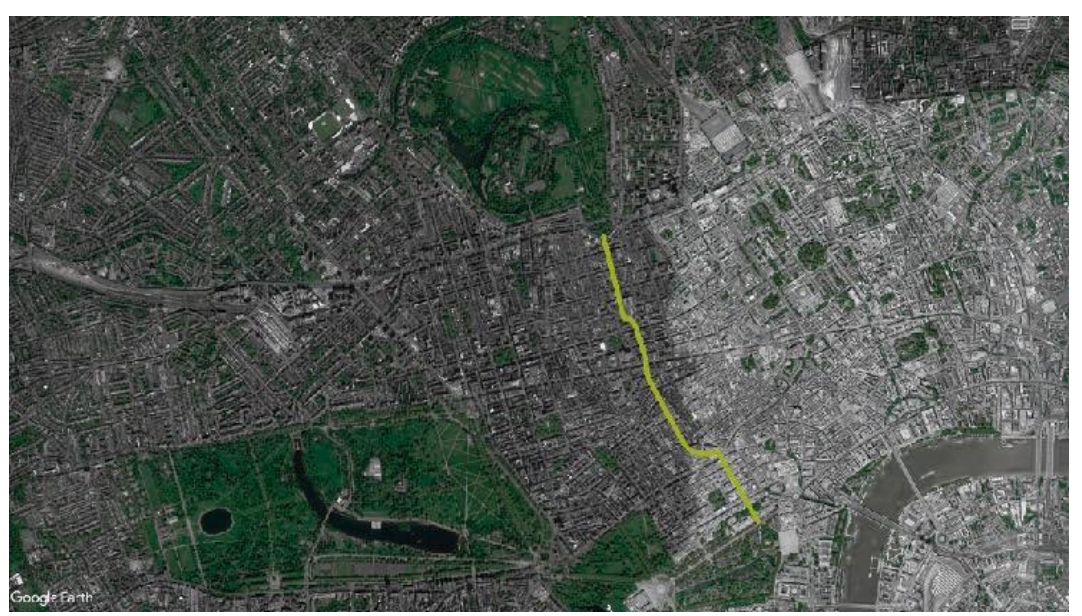

Figure 5. Connection between Regents Park and St James Park. Footprint of the 1810 Project

Source: Adapted from Google Earth 2019.

1853 - Baron Haussmann begins work for the renovation of Paris and, together with Jean-Charles Alphand, the city will be equipped with a series of parks during the Second Empire ${ }^{7}$ (see Figure 6). This Project became an example for other urban renovation projects, especially spurring the City Beautiful Movement in America, and the openning of new public parks and parkways.

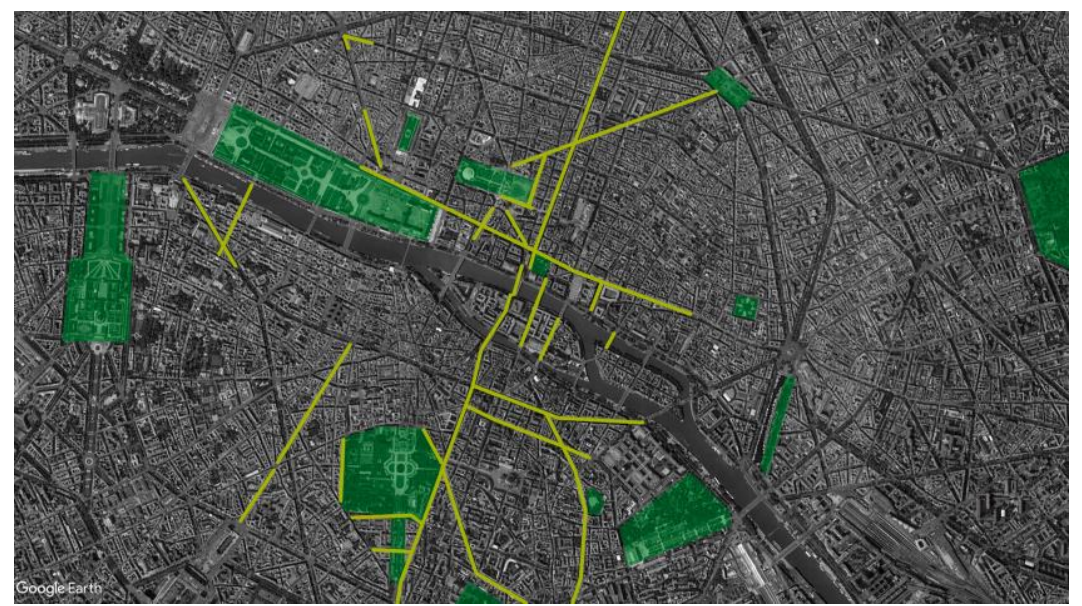

Figure 6. Paris. Footprint of the Boulevards and Parks Begun in1853 by Baron Haussmann

Source: Adapted from Google Earth 2019.

6. Ibid, 201.

7. David, Transforming Paris: The Life and Labors of Baron Haussmann, 1995, 238. 
1858 - Ludwig von Förster designs the Vienna Ringstrasse, ${ }^{8}$ including parks and landscaped squares along a broad avenue-promenade (see Figure 7). This is an example of advantageously utilising the open field and glacis left by the demolition of the Alstadt defensive walls and using this space to build a boulevard and modern facilities that structure new urban gowth and stitch together new and old urban fabric.

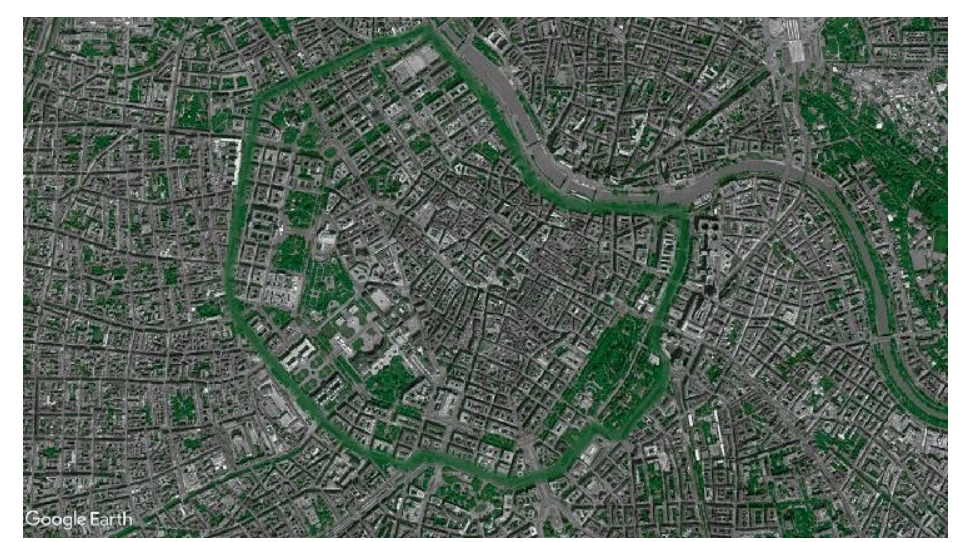

Figure 7. Vienna. Footprint of the Ringstrasse Project around the Alstadt, Begun in 1858

Source: Adapted from Google Earth 2019.

1859 - Ildefonso Cerdà creates the Plan for the Extension of Barcelona, where parks and gardens are integrated in the urban blocks and are a crucial health feature $^{9}$, (see Figure 8). Although the original proposal of having the block cores as unbuilt green open space for ventilation and sunlight purposes was not fulfilled due to intense pressure of real-estate development and land values, the idea of balancing urban fabric with nature is still powerful and influential.

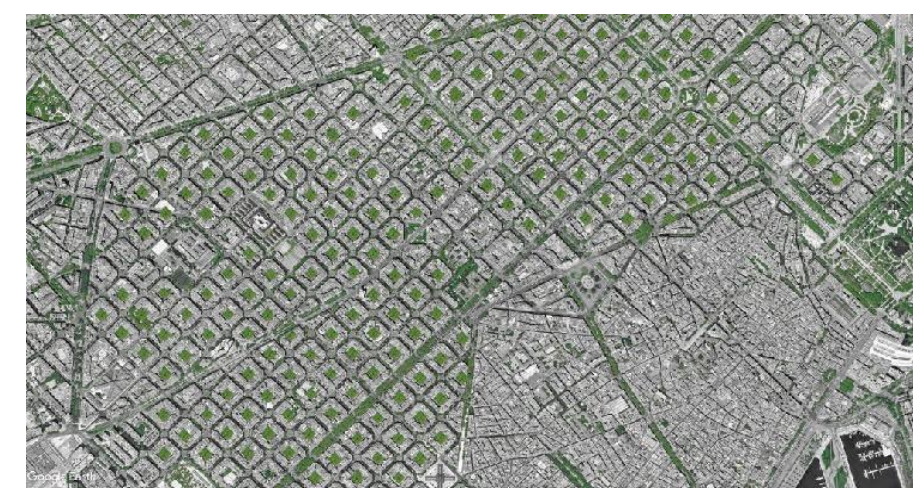

Figure 8. Barcelona, Spain. Footprint of the 1859 Cerdà Urban Project Source: Adapted from Google Earth 2019.

8. Morris, History of Urban Form Before the Industrial Revolution, 1979, 228.

9. Gruppo '2C', "Cerdà's Barcelona. The Elements of Ensanche and Construction of the Block," LOTUS International, no. 23. New York: Rizzoli International Publications, Inc., $1979,86$. 
1867 - Jean-Charles Adolphe Alphand publishes Les Promenades de Paris, testimony of his work with Baron Haussmann and beyond, repositioning the importance of parks and promenades. ${ }^{10}$

1878 - Frederick Law Olmsted designs the Emerald Necklace for Boston, Massachusetts $^{11}$ (see Figure 9). Boston local authorities wished to connect Boston Common with Franklin Park, a country park. Olmsted's proposal was to follow the Charles River, convert the marshland into a winding stream with integrated pedestrian paths as a linear connector park.

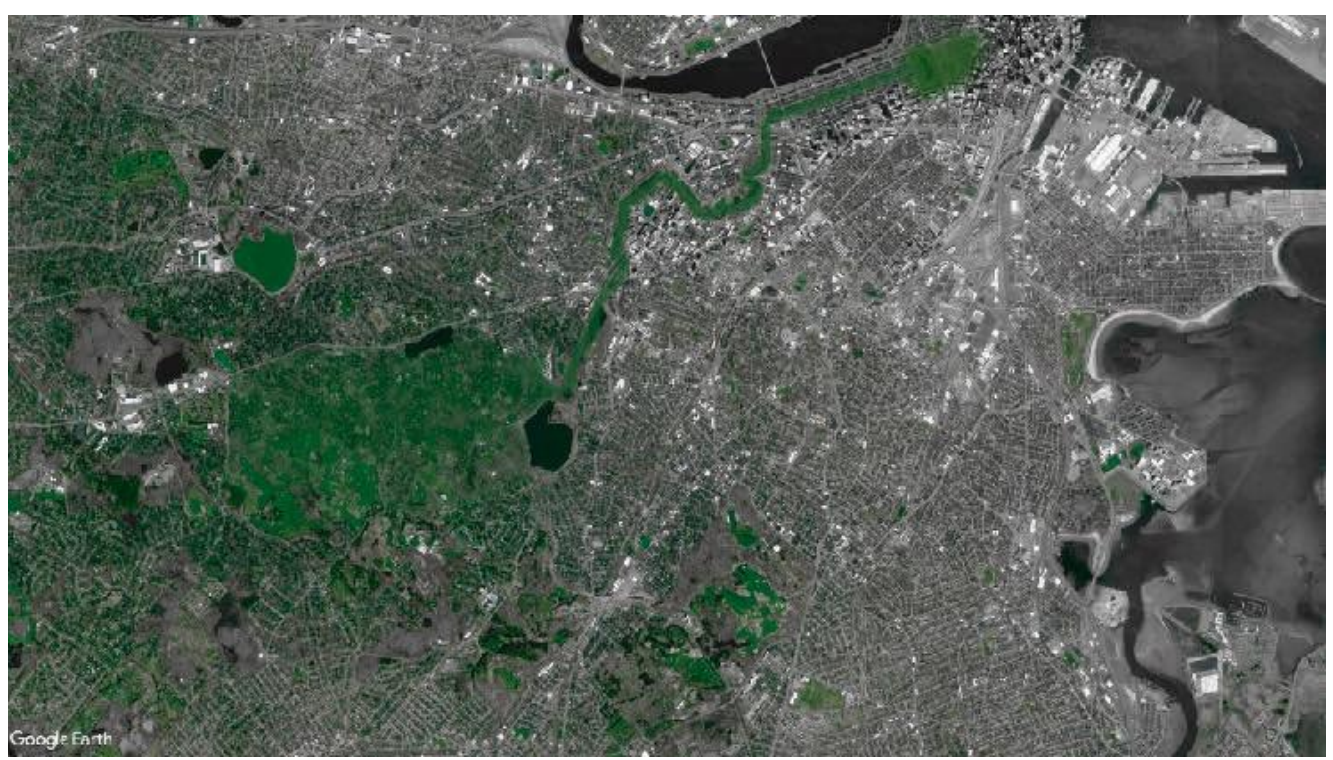

Figure 9. Emerald Necklace for Boston. Footprint of Olmsted's Proposal of 1878

Source: Adapted from Google Earth 2019.

1883 - Establishment of the Minneapolis, Minnesota 'Grand Rounds' Regional Park System and extensive neighbourhood park distribution every 6 blocks ${ }^{12}$ (see Figure 10). This green system also integrates nearby lakes.

10. J. C. N. Forestier, Grandes Villes et Systèmes de Parcs: Suivi de Deux Mémoires sur les Villes Impériales du Maroc et sur Buenos Aires (Paris: Editions Norma, 1997), 29.

11. C. E. Beveridge and P. Rocheleau, Frederick Law Olmsted: Designing the American Landscape (New York: Rizzoli International Publications, Inc., 1995), 98.

12. A. Tate, Great City Parks (New York: SPON Press, 2004), 179. 


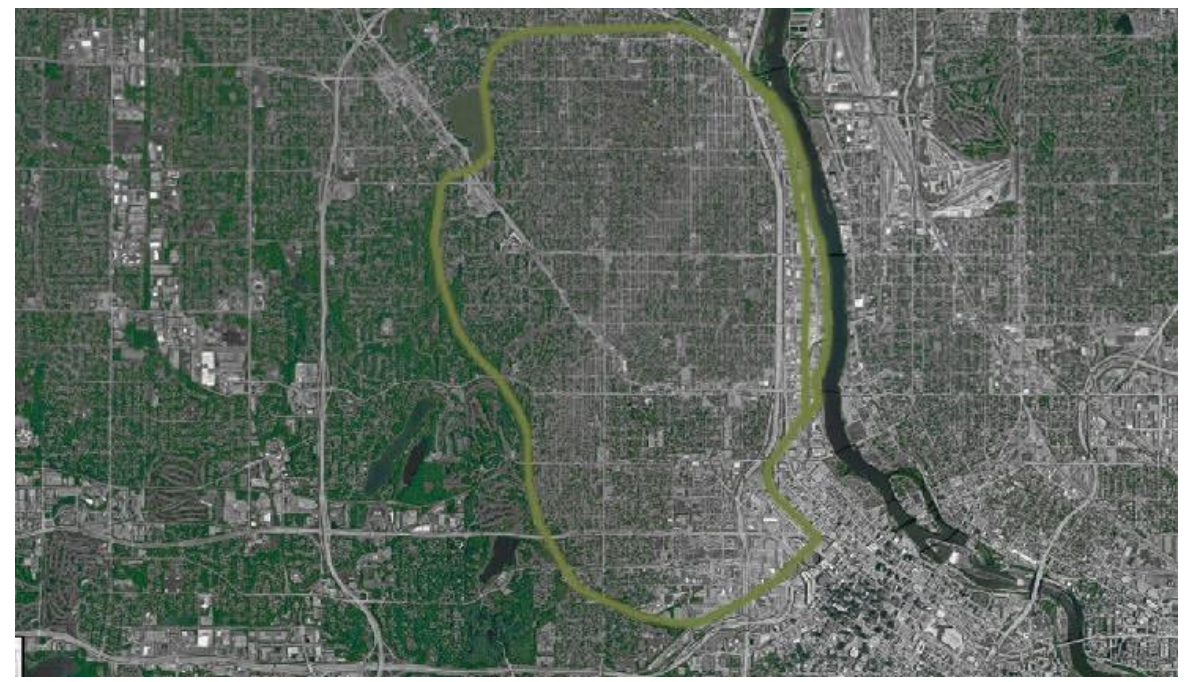

Figure 10. Minneapolis. Footprint of the 1883 Grand Rounds for Minneapolis, Minn., USA.

Source: Adapted from Google Maps 2019.

1902 - Ebenezer Howard publishes Garden Cities of Tomorrow, ${ }^{13}$ combining the virtues of country and city to solve the polluted, unjust, industrialized metrópolis (see Figure 11). The architect Raymond Unwin designed Hampstead Garden Suburb, proposing large municipal parks, tree-lines streets and closes, no walls but hedges between houses, front and back private gardens per house, and a communal garden plot at the centre of a block of houses. This pattern caters to a diversified street and pedestrian complex green system.

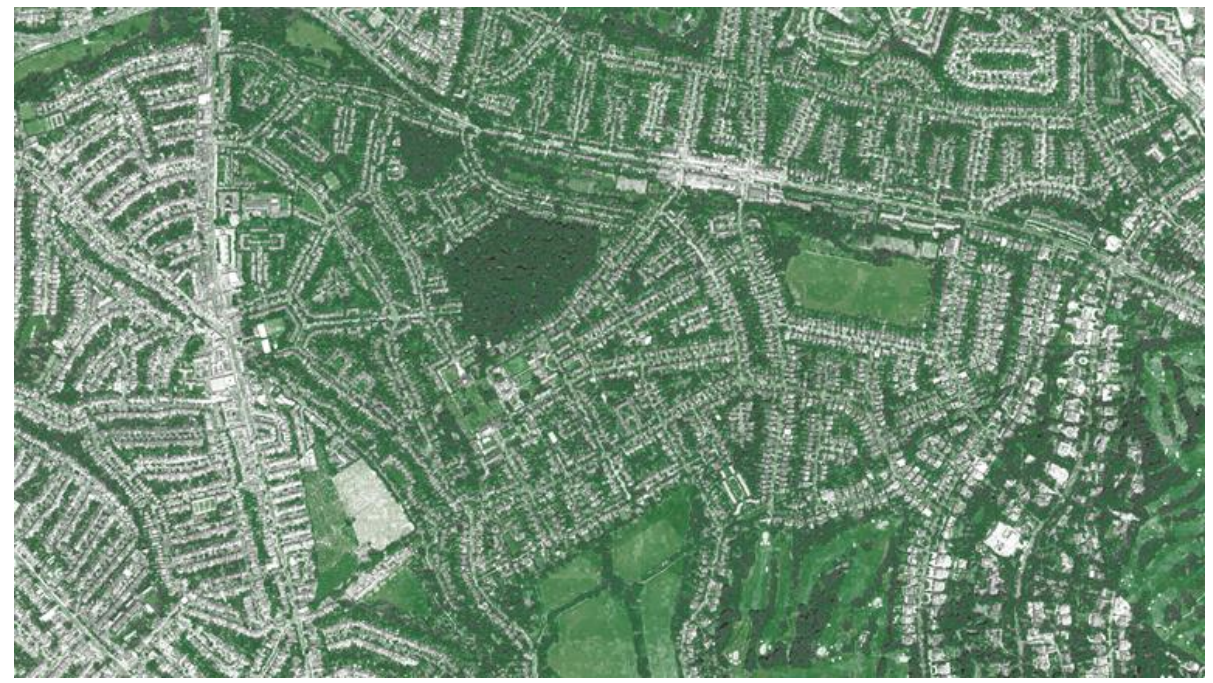

Figure 11. Hampstead Garden Suburb. Footprint of the Raymond Unwin Design Source: Adapted from Google Earth 2019.

13. P. Hall, Cities of Tomorrow: An Intellectual History of Urban Planning and Design since 1880 (Oxford: Blackwell Publishers, 1996), 87. 
1904 - Miguel Ángel de Quevedo establishes plant and tree nurseries in Mexico City to supply plants for parks and boulevards ${ }^{14}$ (see Figure 12). This Forest Engineer followed the footsteps of Nicolas Forestier and donated a generous plot for a first nursery and later established a system of nurseries in different metropolitan areas and climates, while also promoting the National Park System Decree.

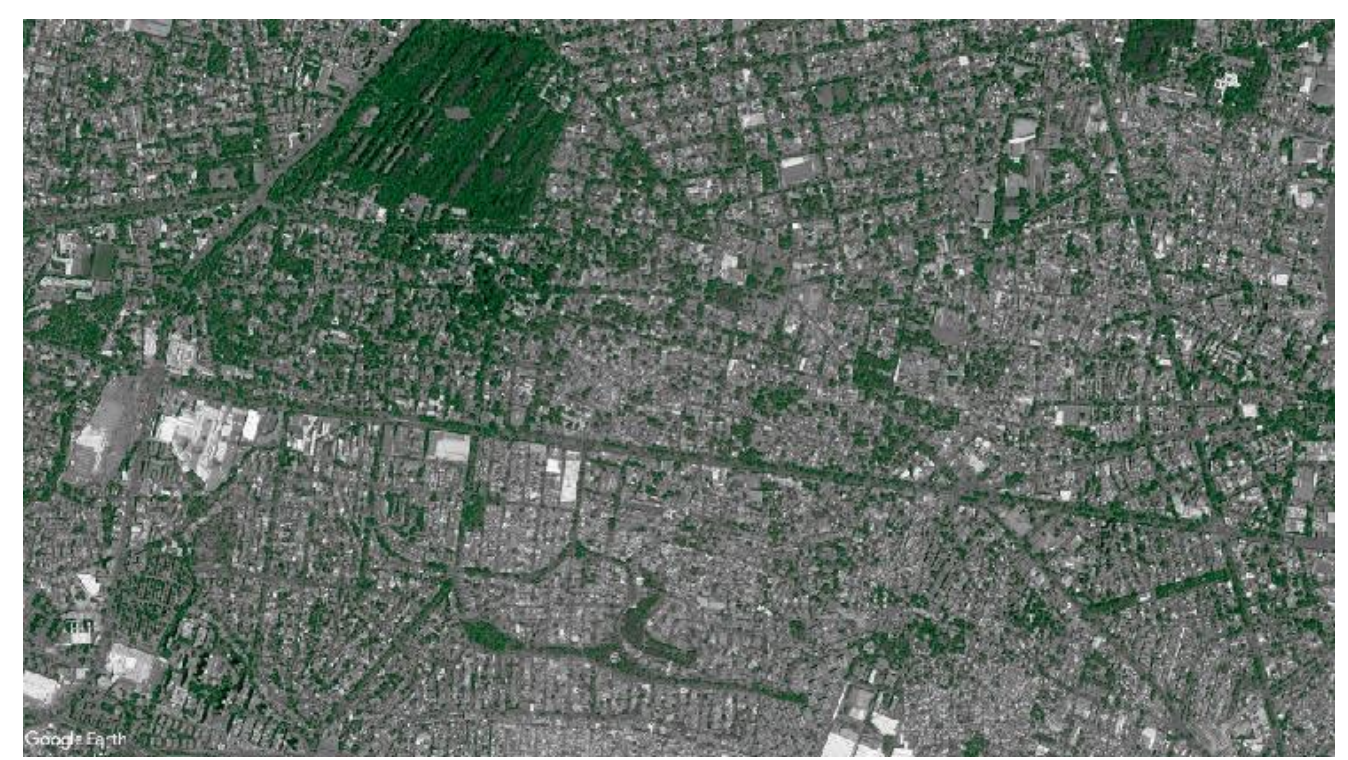

Figure 12. Mexico City. Footprint of First Nursery in Mexico City and Nearby Parks in 1904

Source: Adapted from Google Earth 2019.

1908 - Jean-Claude Nicolas Forestier publishes Grandes Villes et Systèmes de Parcs, where he establishes his theory of park systems, and classification of parks according to scale and function. ${ }^{15}$ He later designed park systems for European and Latin American cities.

1909 - Daniel H. Burnham publishes the Plan for Chicago, which proposes the expropriation of land to build a park system connected by urban corridors ${ }^{16}$ (see Figure 13). This project, although not totally carried out, formed the basis for the present Chicago park system, whereby suburban metropolitan parks and nature reserves were interconnected and protected.

14. E. Eguiarte, "La Ciudad Pensada: Una Ciudad que no Fue. México 1900-1911," in Revista Arquitectónica, no. 6. (ed.) Gigliola Carozzi. Ciudad de México: University Iberoamericana, Otoño, 200482.

15. Forestier, Grandes Villes et Systèmes de Parcs: Suivi de Deux Mémoires sur les Villes Impériales du Maroc et sur Buenos Aires, 1997, 20.

16. C. Moore (Ed.) Plan of Chicago. Centennial Edition (ed.) D. H. Burnham and E. H. Bennett (Chicago: The Great Books Foundation, 2009), ix. 


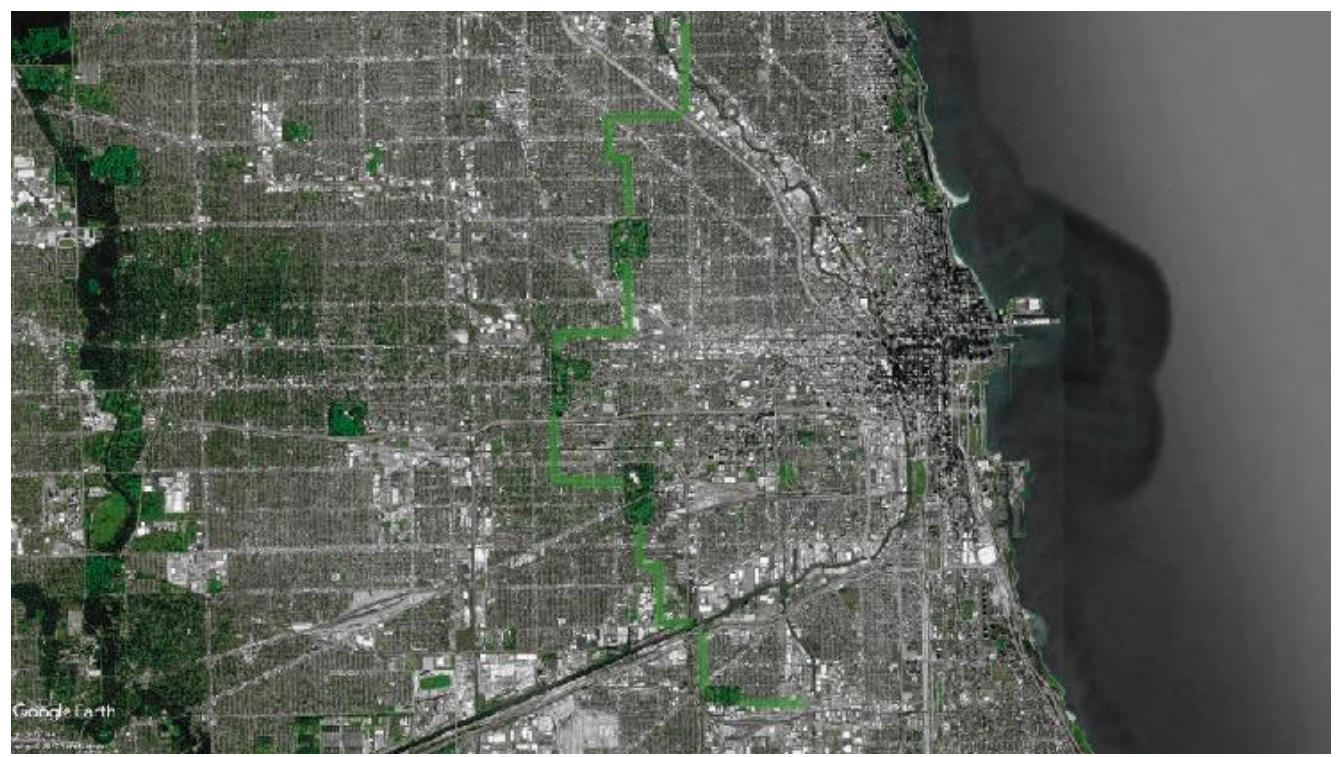

Figure 13. Chicago. Footprint of Daniel Burnham's Park System Project for Chicago in 1909

Source: Adapted from Google Earth 2019.

1912 - Krupp enterprises builds Margarethenhöhe, first garden city in Germany following the design principles of Raymond $\operatorname{Unwin}^{17}$ (see Figure 14). Generous parkland and private and communal garden plots were distributed in this spearheading project.

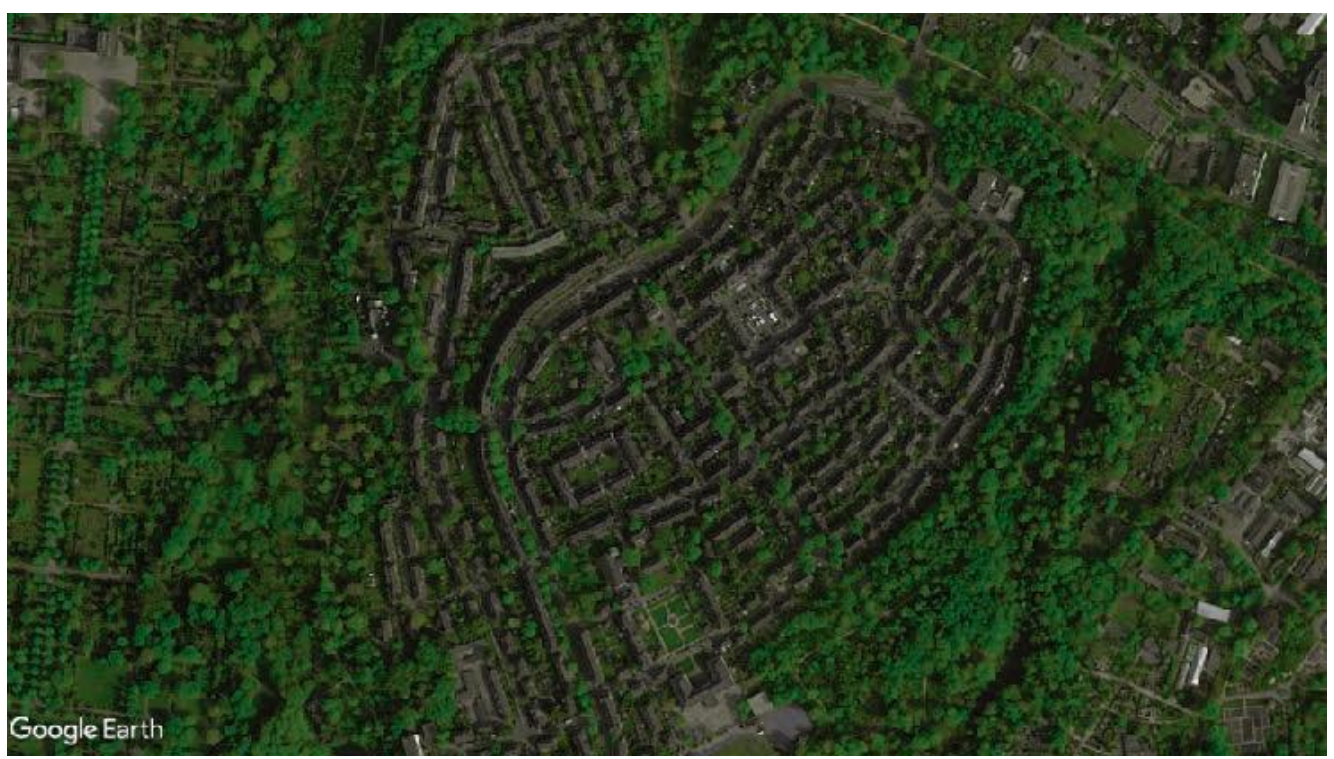

Figure 14. Margarethenhöhe. Footprint of Green Space in this German Garden City Project of 1912

Source: Adapted from Google Earth 2019.

17. Hall, Cities of Tomorrow: An Intellectual History of Urban Planning and Design since 1880, 1996, 115. 
1913 - Edwin Lutyens and Herbert Baker design the layout for New Delhi, India in the 'City Beautiful' tradition, begun by Daniel Burnham in the USA (see Figure 15). The new capital city for the soon-to-be independent India, was designed in a baroque park-like fashion, where green roundabouts and treed boulevards connect the spacious housing plots of a city destined for the British population.

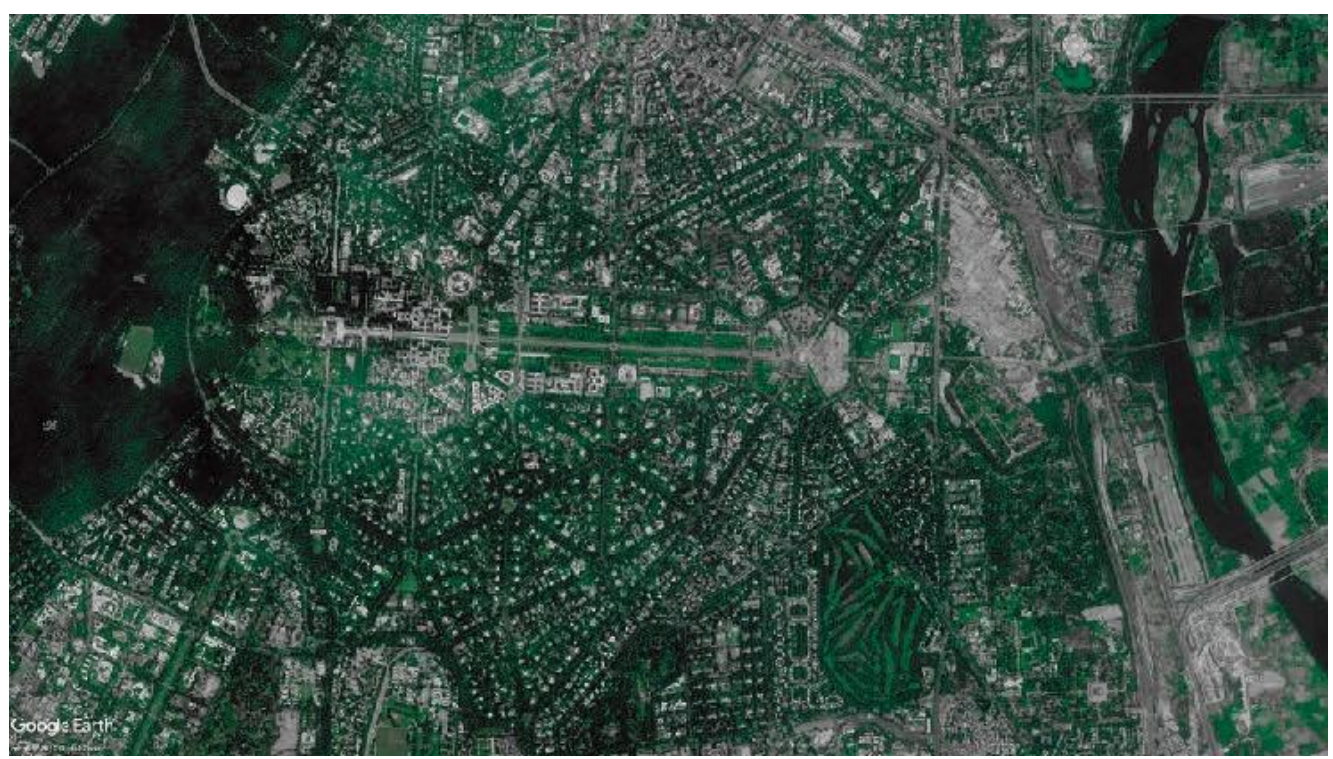

Figure 15. New Delhi. Footprint of the Park System in New Delhi, as per the 1913 Lutyens Proposal

Source: Adapted from Google Earth 2019.

1923 - Jean-Claude Nicolas Forestier proposes a park system for Paris, linking parks with avenue-promenades. ${ }^{18}$

1925 - Ernst May in Frankfurt uses Raymond Unwin's urban design principles for a new low-income neighbourhood Römerstadt, including a system of open spaces $^{19}$ (see Figure 16). This design connects private gardens inside housing blocks with a pedestrian walkway, juxtaposed with the Street network. The pedestrian system culminates in the garden plots and public park at the bottom of the River Nidda Valley.

18. Forestier, Grandes Villes et Systèmes de Parcs: Suivi de Deux Mémoires sur les Villes Impériales du Maroc et sur Buenos Aires, 1997, 38.

19. P. Panerai, J. Castex and J.-C. Depaule, Formes Urbaines: De l'îlot à la Barre (Marseille: Éditions Parenthèses, 2001), 115-119. 


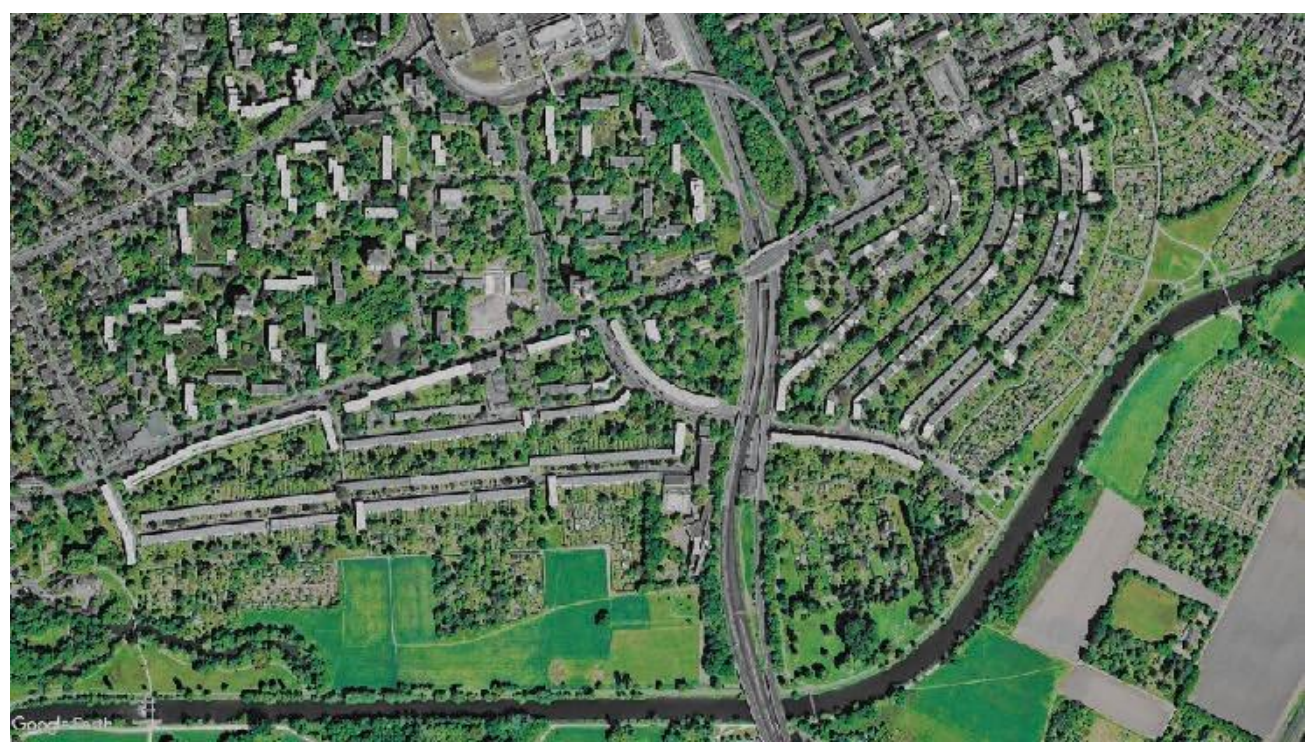

Figure 16. Römerstadt, Frankfurt. Footprint of the Green Áreas for the 1925 Garden City Project

Source: Adapted from Google Earth 2019.

1926 - José Luis Cuevas-Pietrasanta develops the urban design proposal for a new neighbourhood in Mexico City, Colonia Hipódromo Condesa, the park and avenue-promenade being the central feature ${ }^{20}$ and covering almost $40 \%$ of the land (see Figure 17). The design concept integrates de footprint o fan old race track, using the track as a landscaped linear park-avenue, and the infield as a central neighbourhood park.

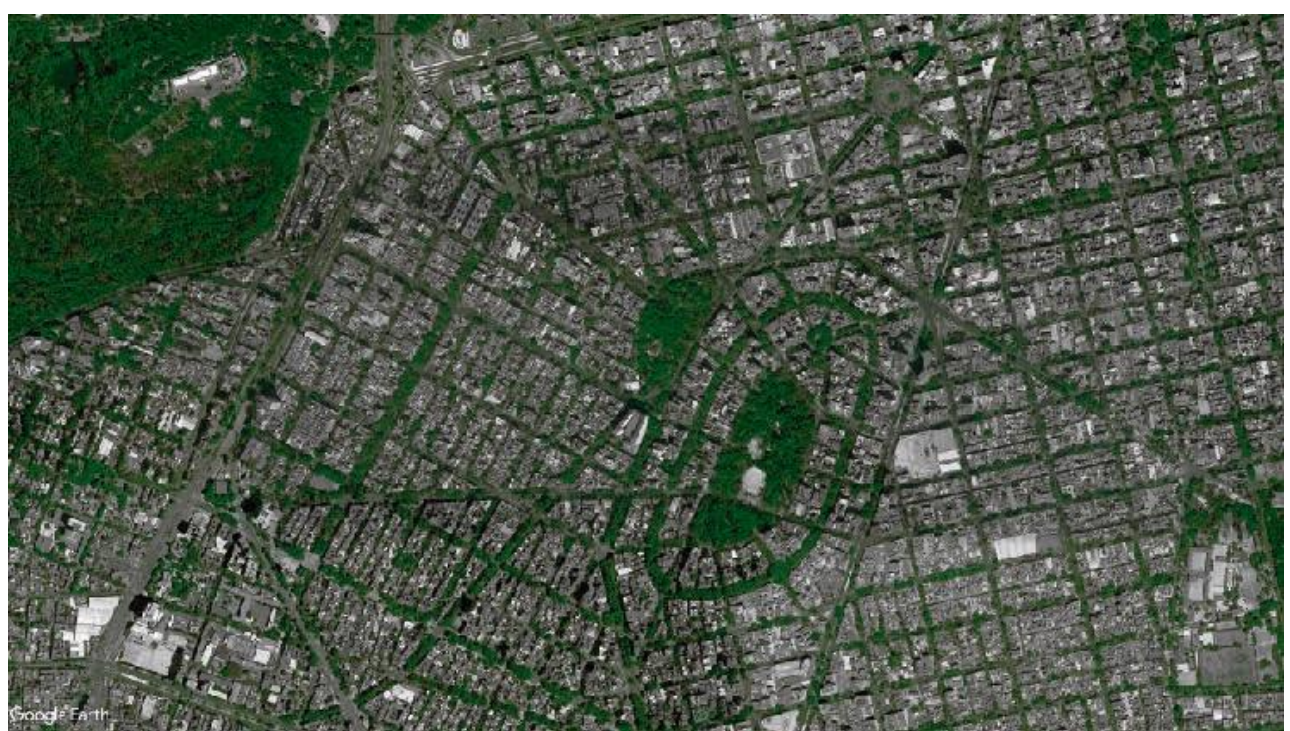

Figure 17. Mexico City, Colonia Hipódromo Condesa. Footprint of Green System in the 1926 Neighbourhood Design

Source: Adapted from Google Earth 2019.

20. Parque México. Wikipedia, la Enciclopedia Libre. Retrieved from: https://es.wikipe dia.org/wiki/Parque_M\%C3\%A9xico. [Accessed June, 2019]. 
1927 - Local government in Washington, D.C. proposed the McMillan Plan to beautify the city. For this purpose, it acquired more than $130 \mathrm{~km}^{2}$ to create a park system of woodlands, ravines and streams, which are currently protected ${ }^{21}$ (see Figure 18). The park system was designed by Daniel Burnham and Frederick Law Olmsted and included the remains of the historical defensive forts from the Civil War period.

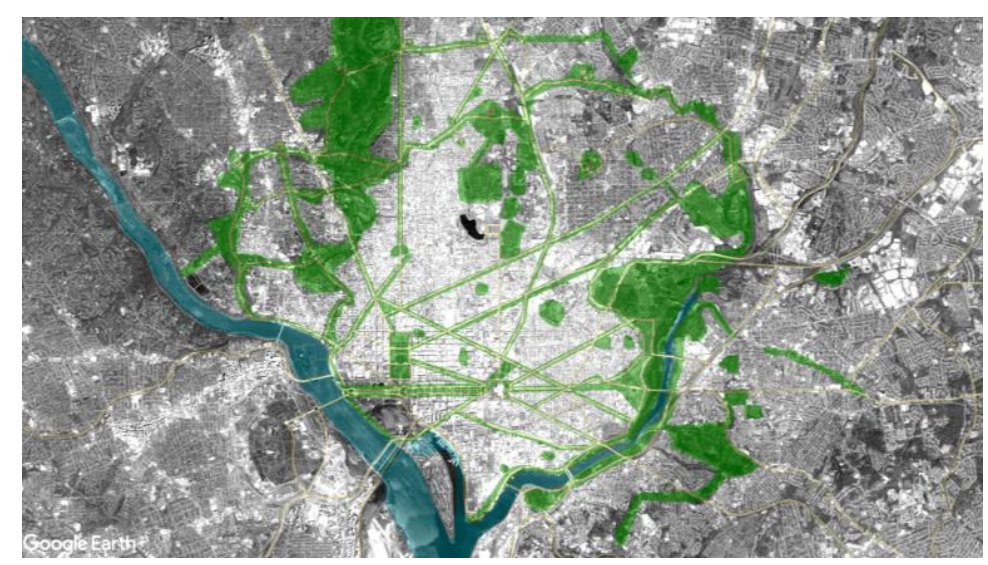

Figure 18. Washington, D.C. Footprint of the McMillan Plan Park System of 1927 Source: Adapted from Google Earth 2019.

1938 - Holger Blom, Head of the Parks Department in Stockholm, builds the first park system in Europe, along the edge of Lake Mälaren ${ }^{22}$ [see Figure 19]. This visionary project encompassed the connection between different scale parks, as well as a lakeshore promenade, making the most of the scenic potential of the wáter.

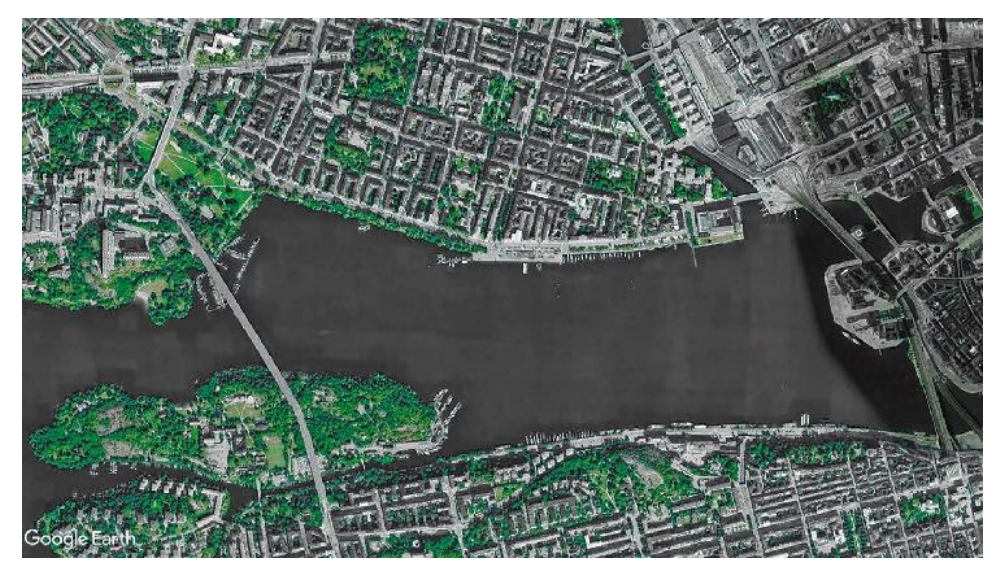

Figure 19. Stockholm. Footprint of the Lakeshore Parks of 1938 Source: Adapted from Google Earth 2019.

21. Hall, Cities of Tomorrow: An Intellectual History of Urban Planning and Design since 1880, 1996, 177.

22. T. Turner, Garden History: Philosophy and Design 2000 BC-2000 AD (New York: SPON Press, Taylor \& Francis Group, 2005), 252. 
1950 - The city of Stuttgart sparks a park system through yearly flower exhibits that encourage the connection between the royal parks and other open areas (Turner, Tom, 2005, p. 252) (see Figure 20). This system of open spaces not only restructured the old city core to integrate it to the new urban growth, but also incorporated a long-lasting social and cultural tradition of festivities.

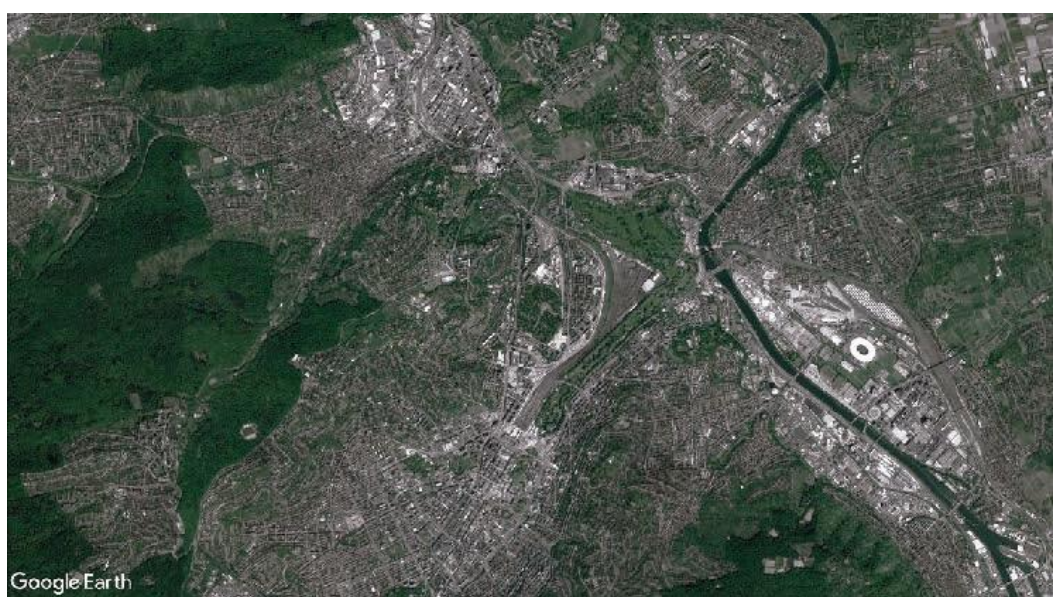

Figure 20. Stuttgart. Footprint of the 1950 Project to Link Old and New City Parks through Flower Exhibits

Source: Adapted from Google Earth 2019.

1951 - Le Corbusier and team carry out the master plan for the new capital city of Chandigarh, integrating a complex park system to the scheme ${ }^{23}$ (see Figure 21). Through the juxtaposition of seven different road network hierarchies onto a green system of parks and pedestrian trails, a burgeoning, intense and densely populated city is rendered user friendly, walkable and efficient.

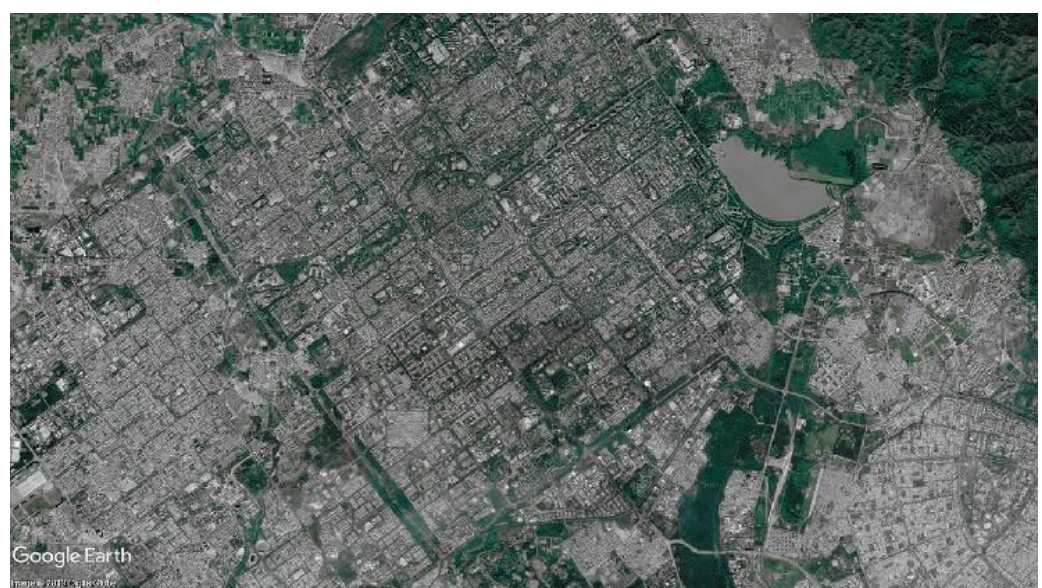

Figure 21. Chandigarh, Punjab, India. Footprint of the 1951 Park System and Road Network

Source: Adapted from Google Earth 2019.

23. W. Boesiger, Le Corbusier (London: Thames and Hudson, Ltd., 1972), 194. 
1958 - Creation of the National Trails System Act in the USA, to form, maintain and protect rural and urban trails for all age groups. ${ }^{24}$

1976 - King Juan Carlos I of Spain entrusts by decree the Turia River causeway to the local authorities in Valencia, to be diverted due to the constant risk of flooding in housing areas along its route. The original causeway is now a linear park $^{25}$ (see Figure 22); one of many examples worldwide where historic natural or man-made infrastructures are transformed to improve urban neighbourhoods it traverses.

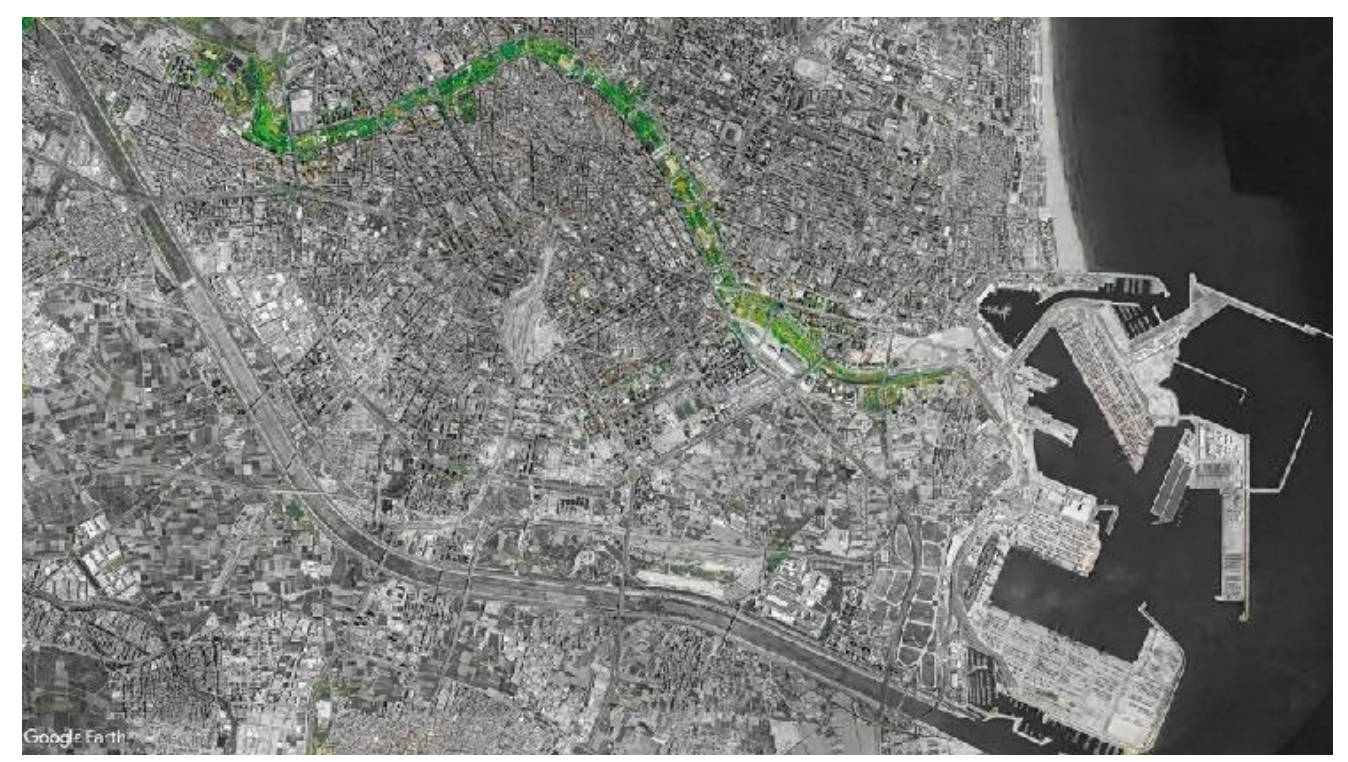

Figure 22. Turia River, Valencia, Spain. Footprint of the 1976 Transformation of a Riverbed into a Linear Park

Source: Adapted from Google Earth 2019.

1988 - Development Plan for Barcelona in preparation for the 1992 Olympic Games, including an open space system recovering public recreational beach and proposing a series of neighbourhood parks $^{26}$ (see Figure 23). This proposal reconceptualises the block and the urban fabric through a series of parks and public squares, following the original Cerdà principles.

24. America's National Trails System. National Trails System. Retrieved from: https:// www.nps.gov/subjects/nationaltrailssystem/index.htm. [Accessed June, 2019].

25. A. Estevan, La Ciudad que Perdió su Río (El País, 2006). Retrieved from: https://bit. $1 y / 30 a s z 4 c$.

26. Turner, Garden History: Philosophy and Design 2000 BC-2000 AD, 2005, 253. 


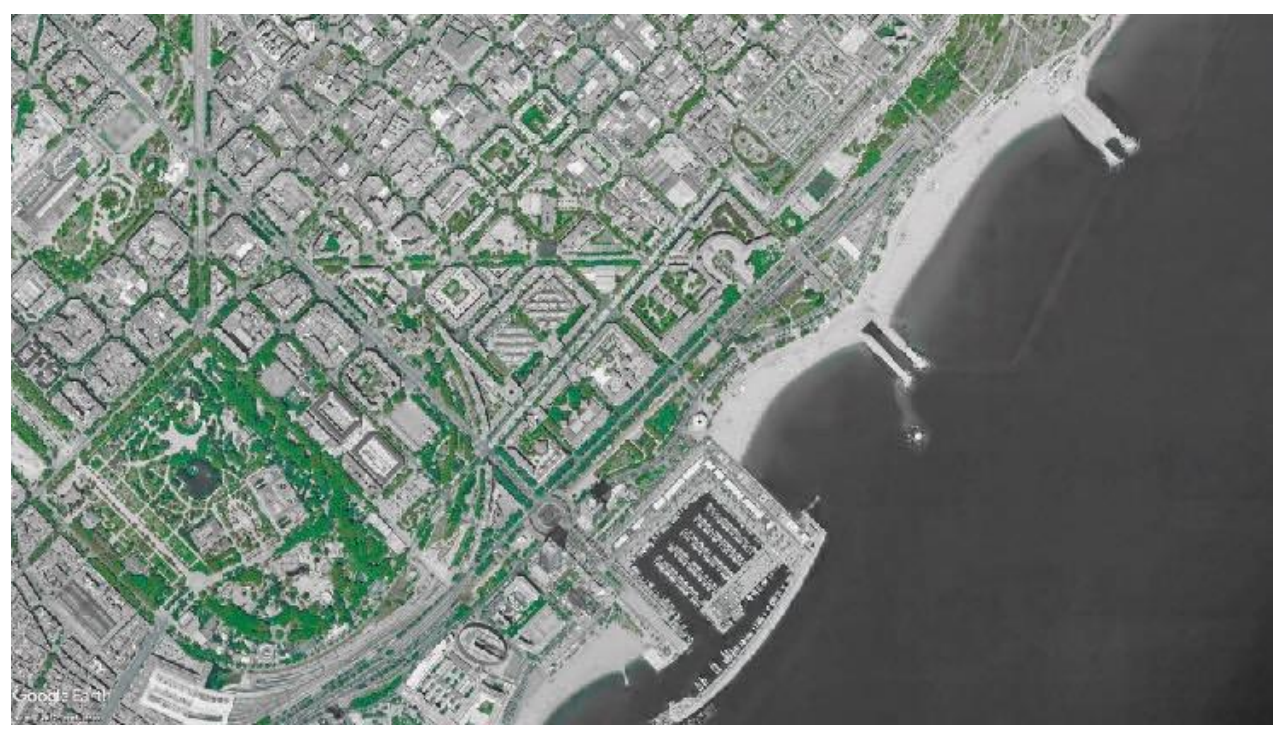

Figure 23. Barcelona. Footprint of the New Block Pattern of 1988 for the Olympic Village

Source: Adapted from Google Earth 2019.

2017 - Groundbreaking of Madrid's Río Manzanares renovation project, creating parks and recreational spaces along its banks ${ }^{27}$ (see Figure 24).

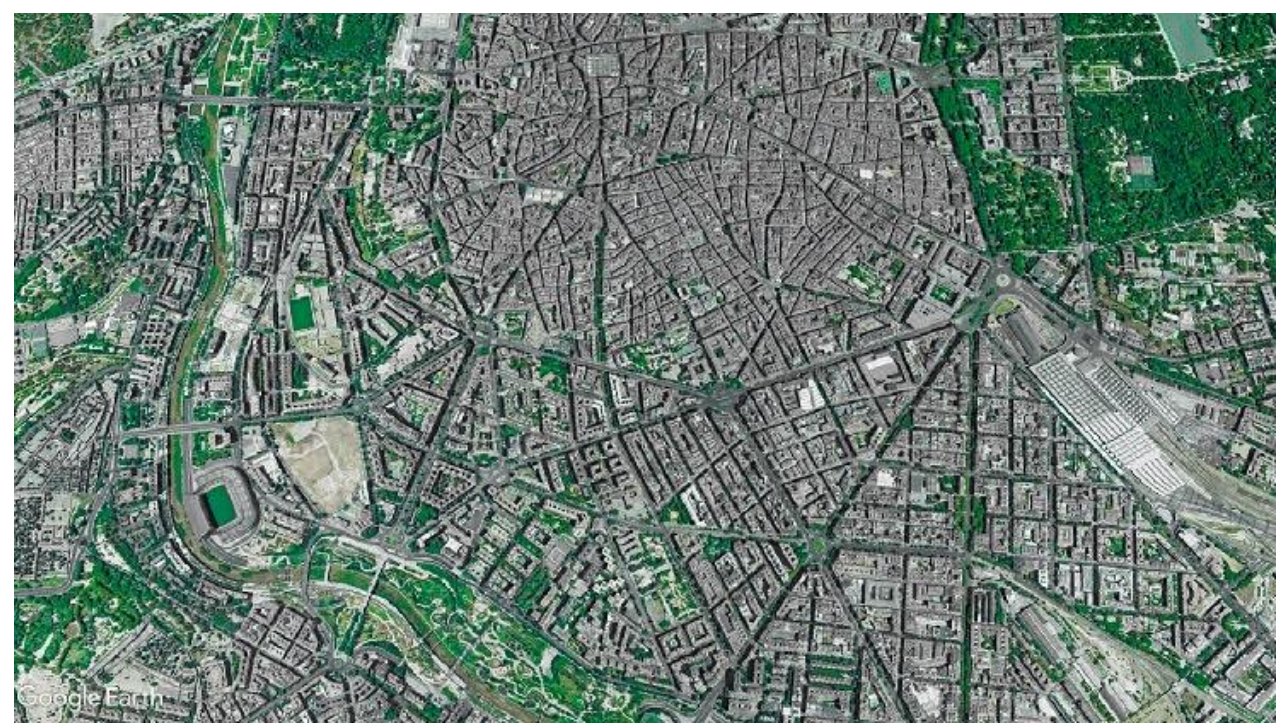

Figure 24. Rio Manzanares, Madrid, Spain. Footprint of the 2017 Urban Riverside Recreation and Landscape Project

Source: Adapted from Google Earth 2019.

The purpose of understanding these historical examples is to become aware of the importance of the public green areas of the city, be they parks, squares, boulevards, ecological corridors, cemeteries, protected areas, and the

27. P. Martí-Ciriquián and C. García-Mayor, "Waterfronts in Spanish Cities: New Urban Spaces," Bitácora Urbano Territorial 28, no. 3 (2018). 
convenience of connecting them to form a system that will enhance walkability and health related issues, as well as strengthen the environmental services and landscape features that open space offers.

Connectors propitiate the migration of species from park to square to playground to natural reserve, as well as supporting the crucial act of pollination. Enhancing the connectors also improves the image of the city, pride of place and stewardship.

Paralell to teaching about the importance of open space is the construction of a theory of park systems, the ideology behind the reality. Different examples give us 'clues' to the intention of the designers, planners or local government officials.

Boston's Emerald Necklace by Frederick Law Olmsted in 1878, for example:

1. Creates a green ring around the Boston City península.

2. Connects urban areas to suburban neighbourhoods.

3. Connects small parks with larger parks.

4. Cleans up and repair the swamp section of the route, with wetlands and other water management features.

5. Uses existing road network as connectors, tree-lining streets and turning them into parkways and promenades.

Stockholm's Park System, along the Mälaren Lake coast, in 1938 by Holger Blom in charge of Parks, for example:

1. Designs far and near landscapes.

2. Uses the banks of bodies of water.

3. Incorporates woodlands.

4. Creates new public parks.

5. Creates connectors.

Stuttgart's Park System, in 1950:

1. Begins with an interesting flower exhibit which became tradition.

2. Connects the Royal Square with the palace gardens, the flower exhibit and the old stone quarry.

Barcelona's park system, for the enhancement of public space and the urban plan for the 1992 celebration of the Olympic Games (Martorell, for example:

1. Returns environmental, landscape and recreational value to the coastline and recovered the use of the beaches for the population.

2. Incorporates green squares and neighbourhood parks in an otherwise dense and greenless urban tissue.

3. Uses public space (including parks) as a form of reconceptualising the city. 
The above examples are park systems that were conceived as such, nothwithstanding the importance of urban forms designed to integrate parks and their connections as part of a meaningful, valuable, identifiable and beautiful neighbourhood or city, abovementioned in the section on 'Initiate'.

Other conditions for the establishment of a park system have been:

1. The purchase of land by the local authority to guarantee the protection of open space as parkland, as in the case of Minnesota Grand Rapids and the Plan for Chicago.

2. The following of some kind of design ideology, for example, 'City Beautiful Movement', in the case of Chicago, in an attempt to improve the image of the industrial city, and 'Garden City' as in the case of Letchworth and Hampstead in England, Margarentenhöhe, Römerstadt, in Germany, to provide quality living to the working class.

3. The re-evaluation of the landscape potential of bodies of water, like for instance, the recuperation of public recreational beach in Barcelona and the re-landscaping of the edges of the Manzanares River in Madrid.

4. The opening and/or restructuring of wide, tree-lined avenues as parkways, promenades and 'connectors' between parks.

5. Considering un-conventional open space as 'parkable', like cemeteries, ground-level sections of ramps and second floor freeways, high-power lines, obsolete railway rights of way and old industrial sites.

Literature on parks and recreational open space has evolved from the $19^{\text {th }}$ Century to this day. What was called parks and park systems is now 'boundless space', a term used by Tom Turner ${ }^{28}$ (1996); or 'green systems' by Andrés Duany and Elizabeth Plater-Zyberk; ${ }^{29}$ or 'biodiversity corridors', by Douglas Farr ${ }^{30}$; or 'recreational systems, ${ }^{, 31}$ by Lance Jay Brown; influenced by the more recent environmental and social considerations, which strengthen and diversify the significance and potential of park systems to adapt to a variety of contexts.

The examples viewed above are indicative of the different planning strategies that they encouraged and upheld. There are clues to be found in the construction of a park system theory that could have the benefit of successful historic proposals of the past, as well as be complimented with the planning and design tendencies of today. In this sense, academic exercises may prove a valuable tool in integrating ideas.

With the intent of teaching the importance of a park system as part of a planning strategy, the content of this course embraces a process whereby the

28. Turner, City as Landscape: A Post-Postmodern View of Design and Planning (London: E \& FN Spon, 1996), 182.

29. A. Duany, E. Plater-Zyberk and R. Alminana, The New Civic Art: Elements of Town Planning (New York: Rizzoli International Publications, Inc., 2003), 168.

30. D. Farr, Sustainable Urbanism: Urban Design with Nature (New Jersey, John Wiley \& Sons, Inc., 2008), 120.

31. L. J. Brown, D. Dixon and O. Gillham, Urban Design for an Urban Century: Placemaking for People (New Jersey: John Wiley \& Sons, Inc., 2009), 110. 
exercises go from the personal to the social content, from the individual space and neighbourhood, to the city as a whole.

After students learn about the meaning of Nature as a historical concept; about how humankind has produced and understood landscape and how the impact greenery and parks has on urban form, they are prepared to continue the teaching process whereby they acquire design skills, typified through action verbs: 'Gaze', 'Imagine', 'Understand', 'Discover', 'Acknowledge/Give Value', 'Propose', that represent different scales of design efforts.

\section{Gaze}

"There can be no places without paths, along which people arrive and depart; and no paths without places.",32

The departure is a park stored in our memories. It can be the souvenir of a picnic or a football match; the first bee sting, or the time we learned to bike without using training wheels. Whether it is playing hide and seek, or holding hands with our first date, the park often takes the place of an important setting for our personal story.

Goals and Expectations of the Exercise: Portrait of Place

Students are encouraged to think of a meaningful moment in which the park was the setting. They ponder about the role of the park in their own life experience.

Every student needs to pick a public place. The goal is to become aware of a specific space only through what they perceive.

- How do people behave?

- What sounds are heard?

- What distinguishes these places from others?

- How does it change throughout the day? What are the different bits that can be assembled to tell a story?

- What elements determine its essence?

- What kind of boundaries delimit space?

- Asking different questions and answering them.

Students need to put together the puzzle of all their annotations and turn it into a message in an artistic form. They can use any means of expression to show what they learned from deeply 'mind-gazing' and reflecting on the place they picked.

32. T. Ingold, The Temporality of Landscape. Contemporary Archaeology in Theory: The New Pragmatism. $2^{\text {nd }}$ Edition (ed.) R. W. Preucel, S. A. Mrozowski (Blackwell Publishers Ltd, 2010), 71 . 


\section{Examples and Findings}

Students engage with their own learning path when they realize that their perception is taken into account. Art-based exercises are ideal for encouraging students to explore something, and also to delve into how they feel about that something. This exercise awakens their enthusiasm because they are allowed to express themselves freely and subjectively. The images below show the diversity of projects.

\section{“Designed Cage” by Roxana Carina Hernández Pineda}

The aim is to generate a complete landscape in one flat picture that shows both sides of a road in the municipality of Huixquilucan, Mexico. This road creates a social limit separating the low-income area (San Fernando) form the privileged one (Interlomas) (see Figure 25).

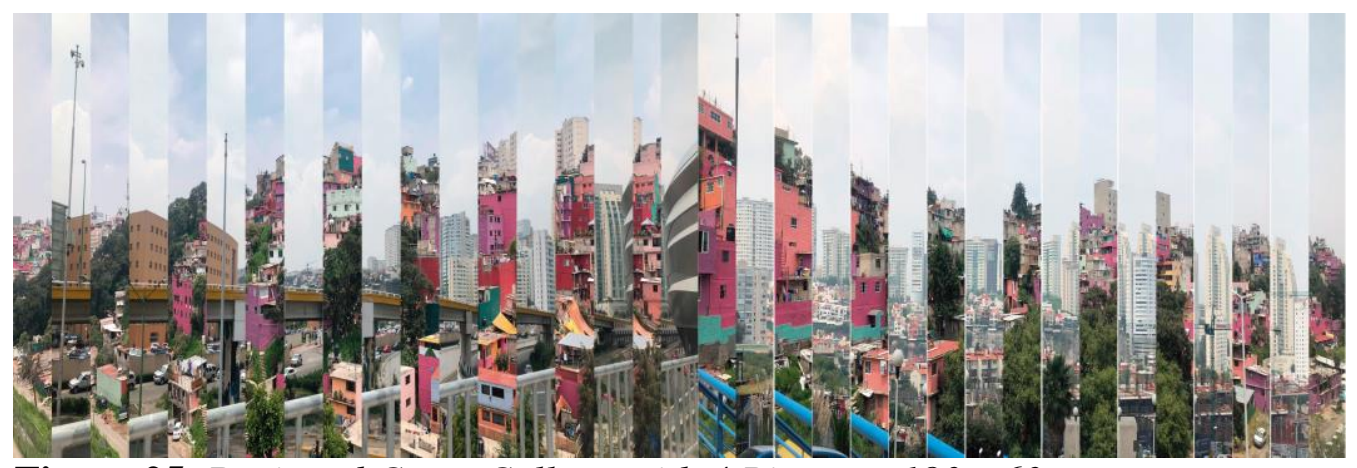

Figure 25. Designed Cage. Collage with 4 Pictures, $180 \times 60 \mathrm{~cm}$

Source: Elaborated by Roxana Hernández Pineda 2018.

\section{“Espacio Escultórico”, UNAM by Fernando Gómez.}

"Espacio Escultórico" (Sculptural Space) is located in the ecological reserve of El Pedregal de San Angel. This sculpture is formed by series of 64 slopes placed forming a circle. The work is composed of a series of photographs that seek to unveil the true essence of the place. The photos were taken from each of the 64 slopes towards the center of the hoop, however none of them are identical. The hypothesis is then that if we could see the space from each of these perspectives at the same time, we would capture the essence of this sculptural space in its totality (see Figure 26). 

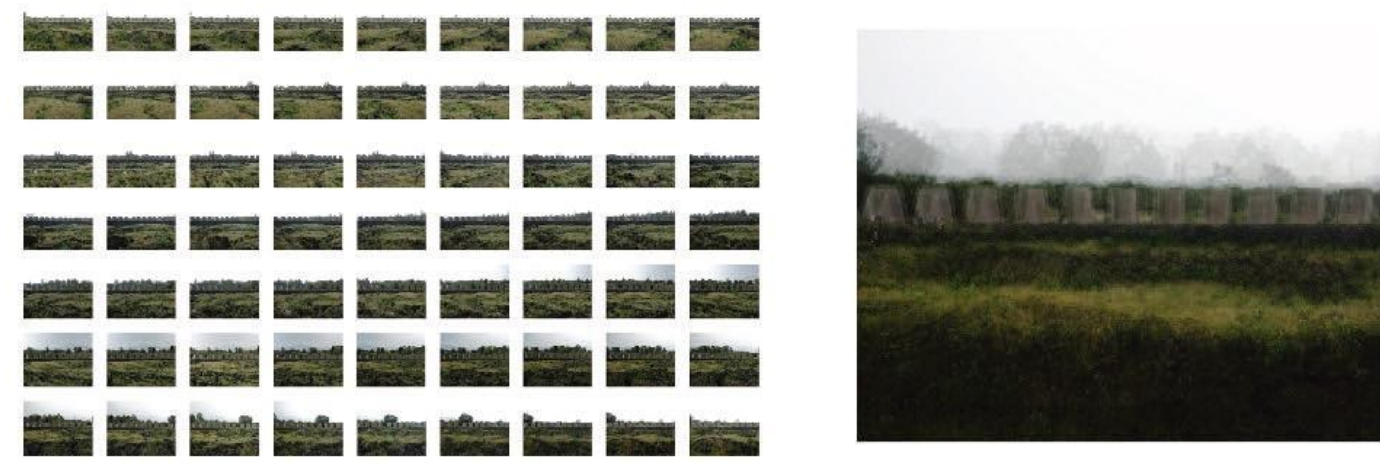

Figure 26. Espacio Escultórico I. Series of 64 Juxtaposed Photographies

Source: Designed by Fernando Gómez 2018.

"Fragments" by Viviana Flores

The aim was create an image that evoques a multi-sensorial experience, showing how people behave and feel in a park, expressed in vignettes (see Figure 27).

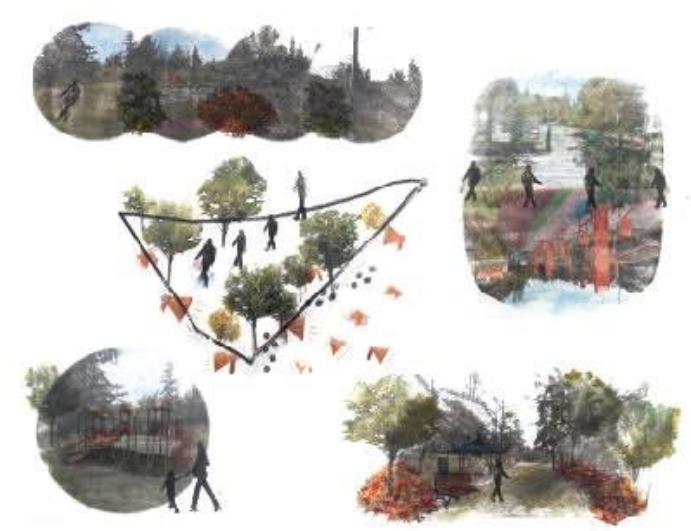

Figure 27. Fragments. Mixed Media

Source: Designed by Viviana Flores 2019.

Imagine

Designing fictions offer a rich arena for visualising future life and picturing its dangers and promises. The 'Ideal something' helps each person identify what is central to her or him, but might be hard to put into words. It is important to contrast ideas that create new symbols and build culture.

Goals and Expectations of the Exercise: Ideal Park

Students create a graphic representation of their ideal park. By sharing their work, students may understand, relate, give visibility, or discuss, the prerogatives of other classmates. This exercise gives rise to a powerful debate on values and an interesting contrast in backgrounds, which encourages sociability 
among the members of the group, as well as acceptance of each other (see Figure 28).

\section{Examples and Findings}

Tacit knowledge, such as emotion, intuition, and experience, takes an important role on the students education. Thinking about their ideal park reminds them that they can be the change they want to see in the world. Enchantment is a key aspect for designing a better tomorrow. When presenting and discussing each approach, multiple narratives and viewpoints are knitted together, and create a common utopia, a shared purpose for designing open space.
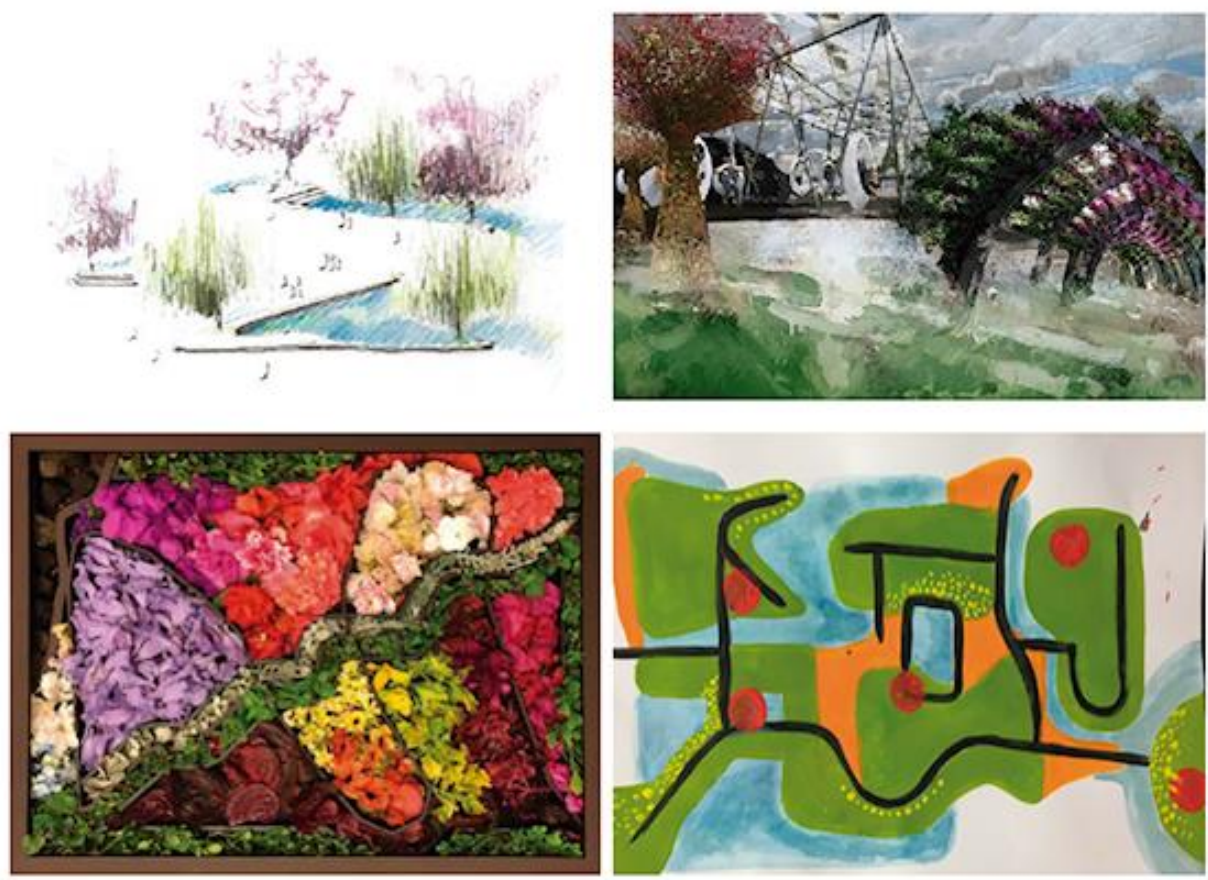

Figure 28. Ideal Park. Mixed Media

Source: Clockwise from top left. Designed by Bruno Villarreal, María Fernanda Becerra, Viviana Flores and Renata Luna, 2019.

\section{Understand}

The sense of a place can be understood by seeking authentic human attachment and belonging.

Constructively, we have given meaning to the concept of the park by making a catalogue of commonplaces and distinctions. Through research of authors writing about the park and about the city, and other sources of information, including user, designer and manager surveys, as well as newspaper articles and song lyrics, the idea of the park is very diverse depending on the particular audience.

In general, the urban park is a Moral Place. It combines the aesthetic and ethical values of Nature and Democracy. Specifically, the park is a variegated set 
of values that range from the personal search for beauty, health, action, to the collective search for safety, community and identity.

Goals and Expectations of the Exercise: Survey and Illustrate

Students conduct surveys in order to understand how the concept Park is understood by the people in and outside their community. This exercise fosters empathy and the awareness of the advantages of diversity. They gather information and interpret the obtained results in order to understand what others consider important.

Some of the people surveyed have volunteered a personal drawing of how they imagine their ideal park to be. These renditions offer rich new meanings and confirm commonplaces found in other sources (see Figure 29).

Examples

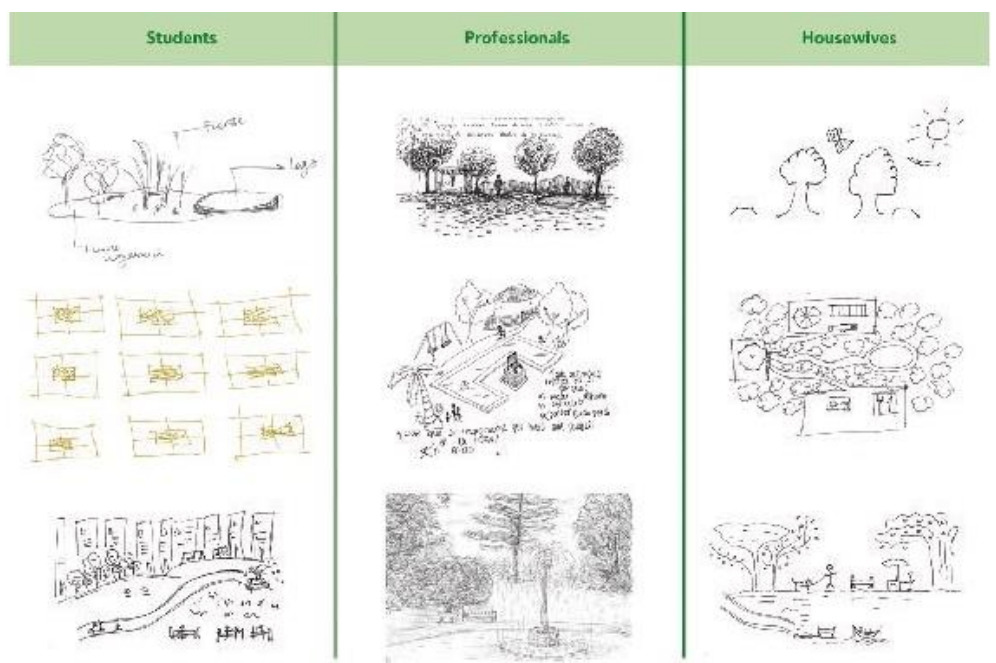

Figure 29. Illustrations Made by the People Surveyed

Source: Provided by the People Surveyed 2018.

\section{Discover}

Students' senses are open to the new possibilities in their own backyard. Sometimes they become far removed from their personal surroundings, so in discovering potential improvement in their neighbourhood, observing the patterns of activity, bringing back childhood memories, fosters their interest in creating a sense of 'place'. What better way but by creating a significant space for family, friends and neighbours.

Goals and Expectations of the Exercise: Green Areas in your Neighbourhood

The exercise "Green Areas in your Neighbourhood" analyse the urban form in their neighbourhood. They identify on a Google Earth Map the existing green areas and open spaces that could be reforested. They search for potential 
connectors between them in order to create a local proposal for a park system. This exercise is a preamble to the city scale they will encounter next (see Figure 30).

\section{Examples and Findings}

Students look at old in new ways. This exercise peels away the habitual disregard for what is around them, enabling the search for existing potentials in their neighbourhoods. At the same time, they develop the skills for analysing urban form and its relationship with green structure. They become aware of the entanglement allowed in a small fragment of the city, and they realise that there is no unique recipe for solving urban problems. Students learn to manage and work with complex information, understanding that the total is more that the sum of its parts. The oral presentation of their proposals serves as a brainstorming session of strategies of the benefits derived from a park system without disregarding the existing urban form.
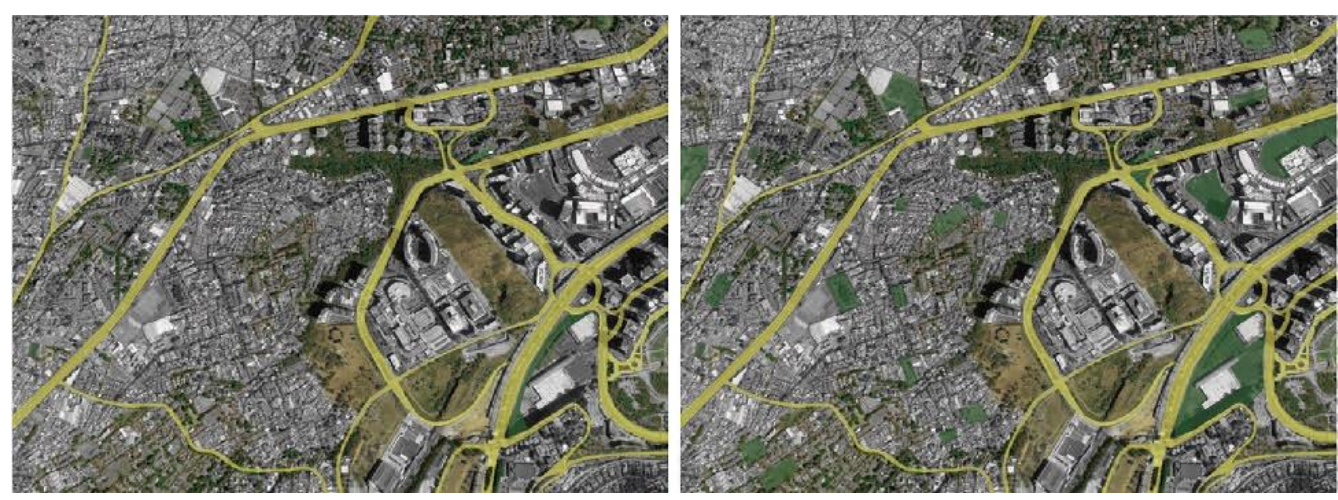

Figure 30. Green Areas in your Neighbourhood: Proposal for Santa Fe Borough, Mexico City

Source: Adapted from Google Earth by José María Hernández 2018.

\section{Acknowledge/Give Value}

This is the exercise where students begin to analyse Mexico City in a different way than they have been doing in their regular design studios. They will be working at a different scale altogether, they will be working in pairs and then working together as a group. This exercise involves teamwork between 15 to 18 students. They begin by studying historic maps of Mexico City to find old structures that may or may not be present today. This will be the starting point of their proposal.

Goals and Expectations of the Exercise: Historical Systems

A section of a map of Mexico City is divided into 9 sections. Each section is assigned to a group of students. By analysing the urban form and by observing the corresponding section of a historical map, students identify the footprint of old 
infrastructures and patterns, such as: rural roads, aqueducts, plazas, old ditches, and old pathways.

Students juxtapose the non-existent historical elements onto a current map. They search for significant elements that could be restored or repurposed to enhance the identity of each section and the park system as a whole.

The historical maps used were taken from different historic archives. The timeline of these maps shows the limitation of the graphic and survey techniques of their time. They were produced with a difference of several decades between them and were drawn with different information objectives. Some maps only show urban areas and the nearby non-urban fringe. Others show a more extensive territory. Historical elements that still exist have been mapped, juxtaposing those that have disappeared, whose footprint would be worthy of new presence. Following is a summary of changes found between one historic map and the next (see Figure 31):

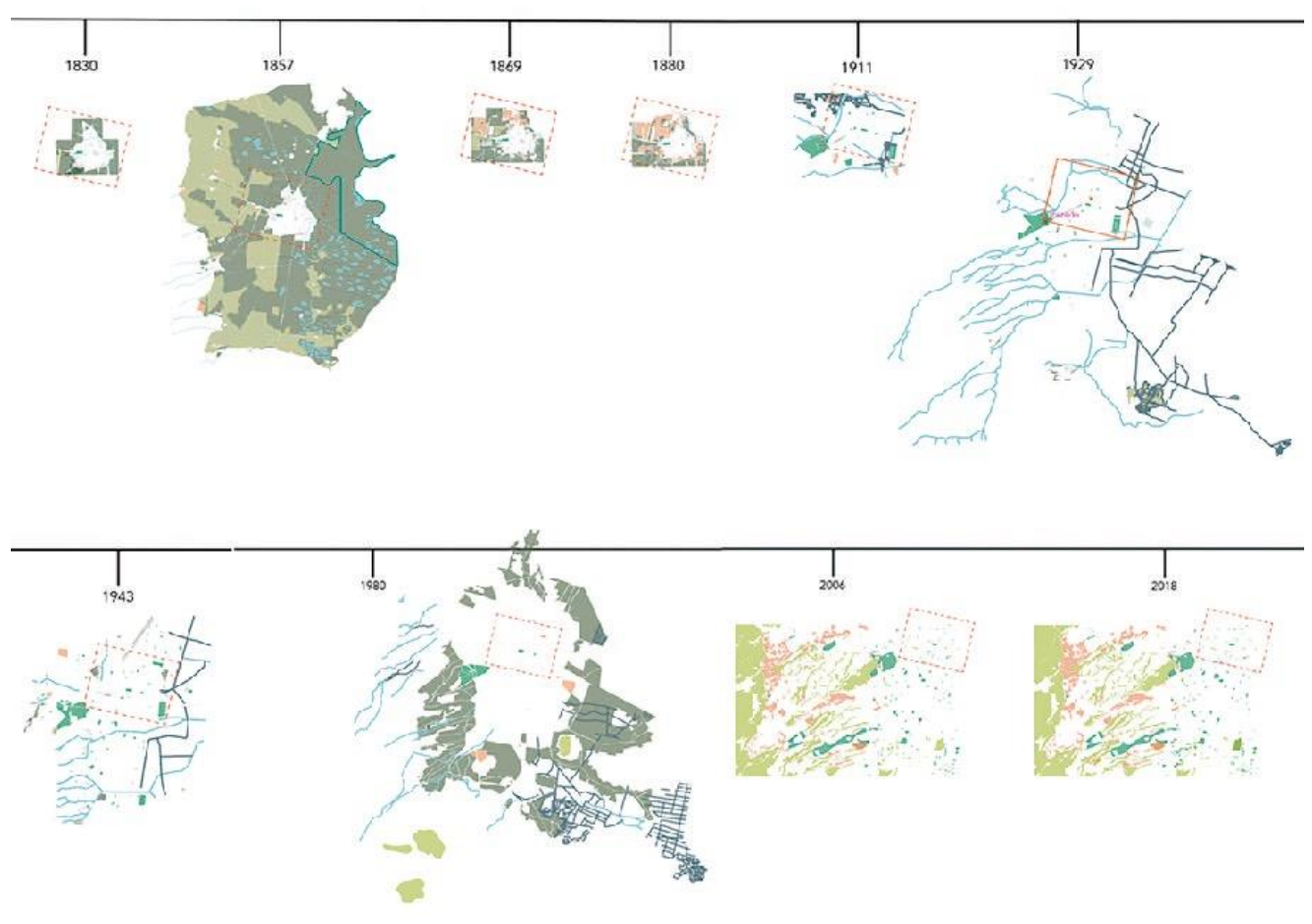

Figure 31. Timeline

Source: Produced by Jocelyn Urióstegui and Melissa Quintero.

Subsequent maps will show this timeline with an auxiliary location map indicating the Mexico City State boundary and the scale of each map observed. 1830 - A system of public squares is represented in a compact city surrounded by non-urban open space and farmland. "La Alameda" is the only park, a historic poplar grove founded by the Spaniards in the 16th Century as a buffer to constant floods from the surrounding lakes. Natural bodies of water, determine and delimit the division of non-urban open space (see Figure 32). 

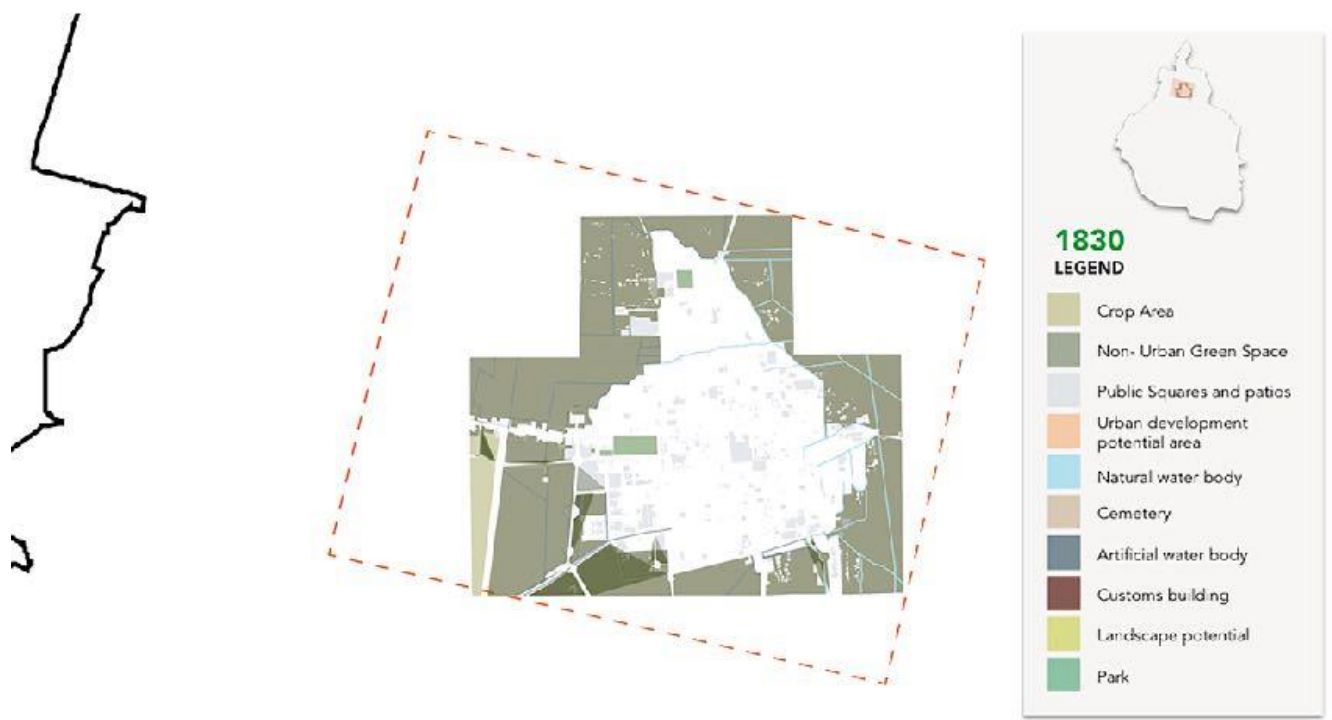

Figure 32. Mexico City, Historical Map 1830.

Source: Produced by Jocelyn Urióstegui and Melissa Quintero.

1857 - Small presence of public squares (some of them in scattered towns, outside the urban perimeter). There continues to be a great amount of non-urban open space and farmland in this representation. A new park appears to the north in the Azcapotzalco region. Many natural bodies of water such as rivers and small lagoons are present, as well as small towns scattered across the territory covered by the map. Presence of old customs buildings which acted as toll booths for entering and leaving the city, as well as official entrances through country roads are present. The customs houses formed a 'boundary' between country and city (see Figure 33).

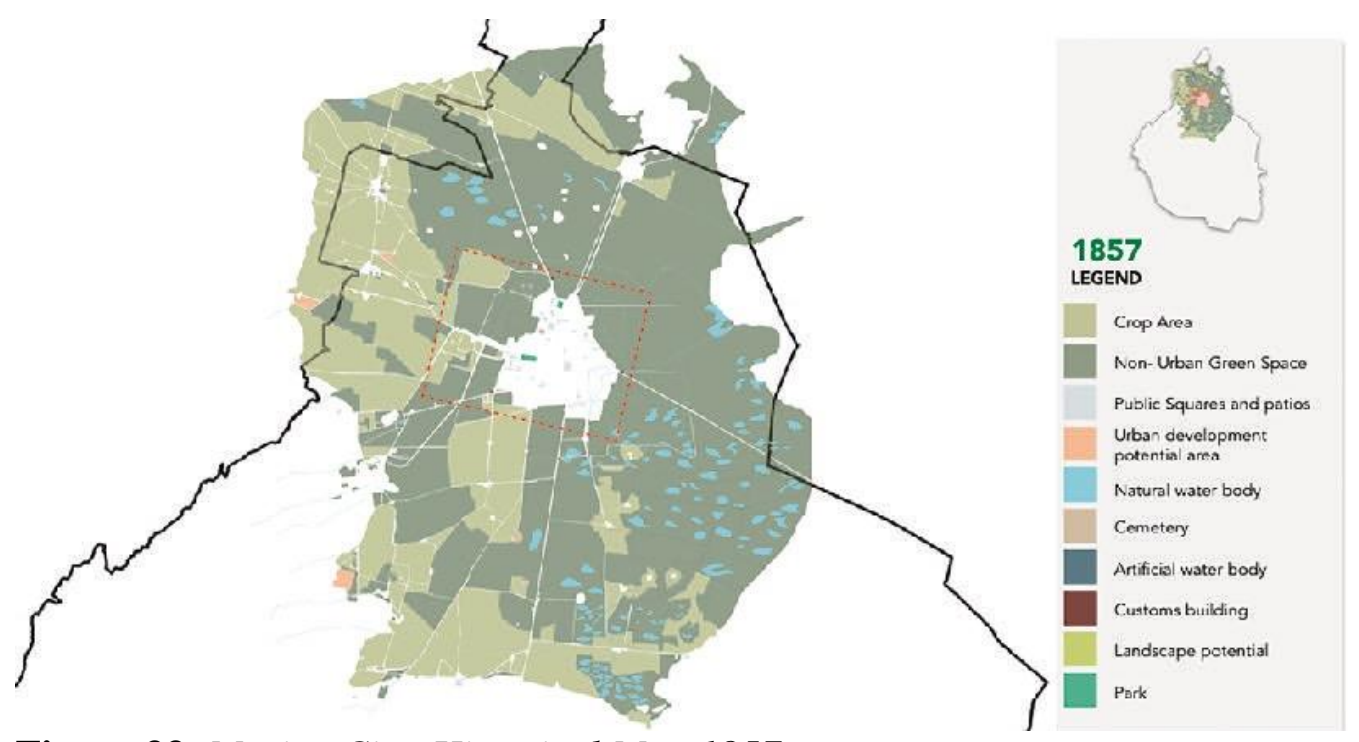

Figure 33. Mexico City, Historical Map 1857

Source: Produced by Jocelyn Urióstegui and Melissa Quintero 
1869 - Few public squares, a decrease in the amount of non-urban open spaces and farmland, and new parks are observed. The existing streams have adapted their course to the extended urban form, giving rise to new artificial bodies of water in the form of canals. The urban core has expanded through new road network, but scarcely any new buildings (see Figure 34).
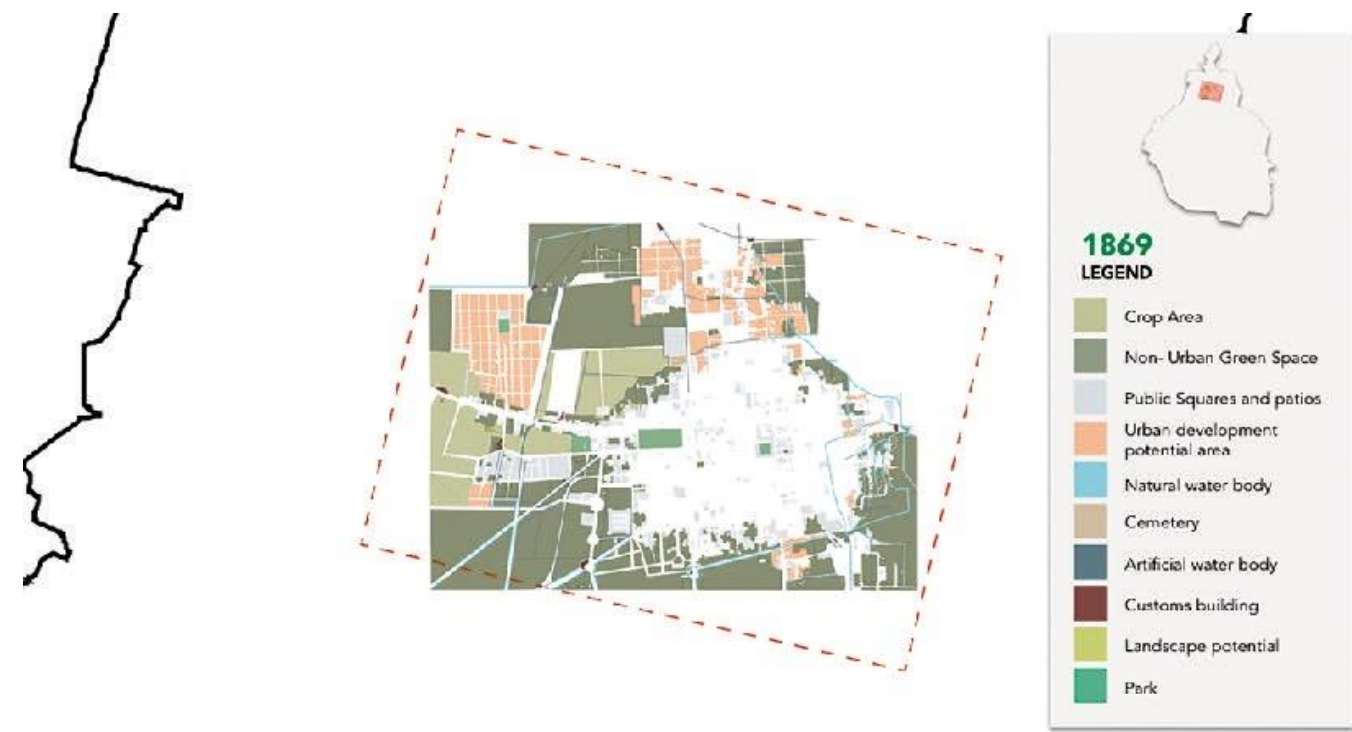

Figure 34. Mexico City, Historical Map 1869

Source: Produced by Jocelyn Urióstegui and Melissa Quintero.

1880 - Still few public squares to be found. These are important open space, as the traditional Spanish square in the New World was generally vegetated. There is a decrease in farmland; parks are still few, and the urban core continues to expand (see Figure 35).
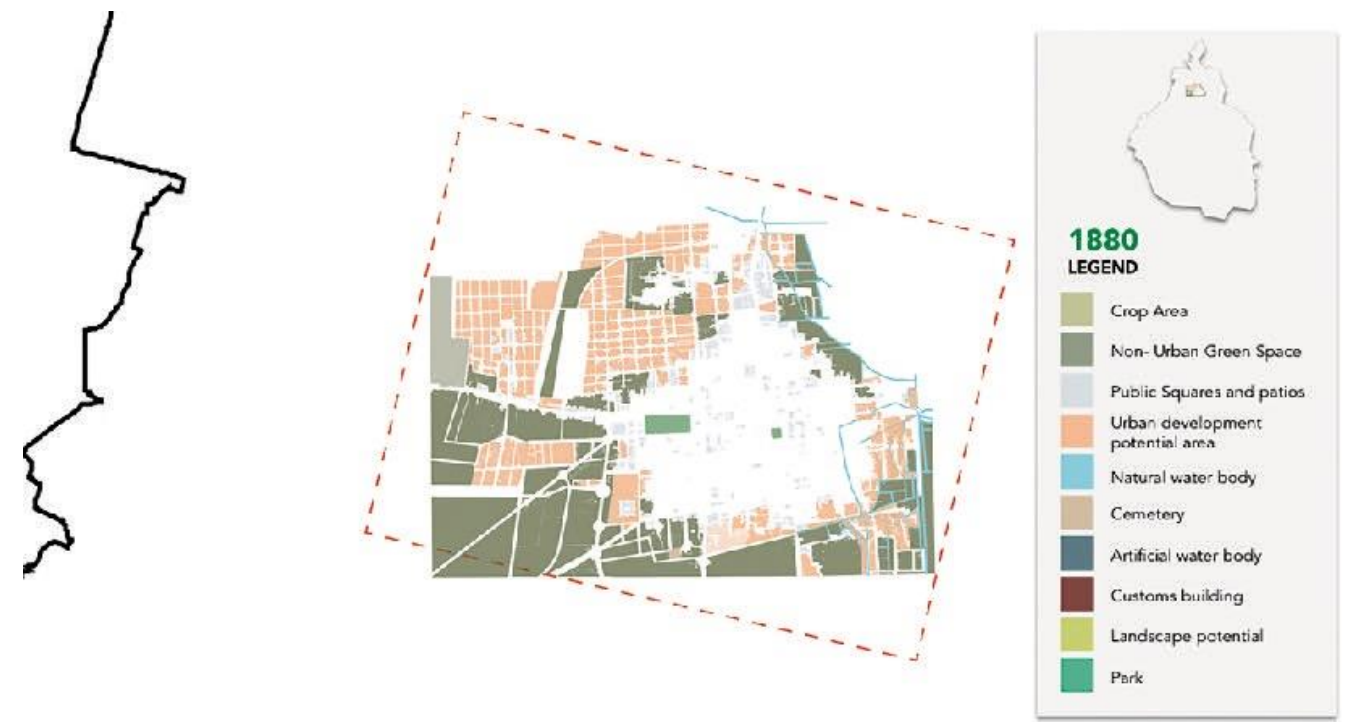

Figure 35. Mexico City, Historical Map 1880

Source: Produced by Jocelyn Urióstegui and Melissa Quintero. 
1911 - The old customs buildings are not represented on the map, and perhaps have been demolished, marking the modernisation and new growth of the city. The presence of inner city green open spaces perhaps helps improve the urban landscape. The city extends south and westward. Chapultepec woodlands become the official 19th century urban park. Rivers are transformed into canals, aqueducts and irrigation ditches (see Figure 36).

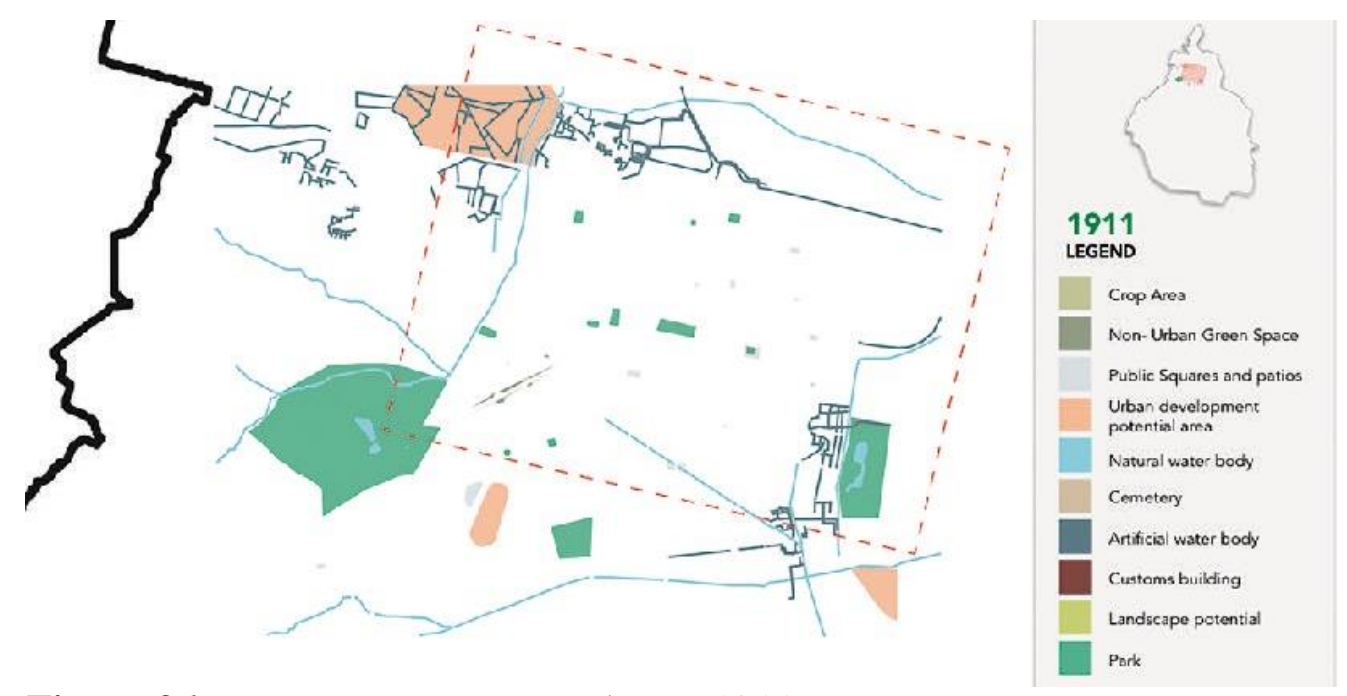

Figure 36. Mexico City, Historical Map 1911.

Source: Produced by Jocelyn Urióstegui and Melissa Quintero.

1929 - The city experiences exponential growth to the South and the West. Greater presence of artificial water bodies can be observed. There is an increase in the amount of small parks and emergence of tree-lined streets (see Figure 37).
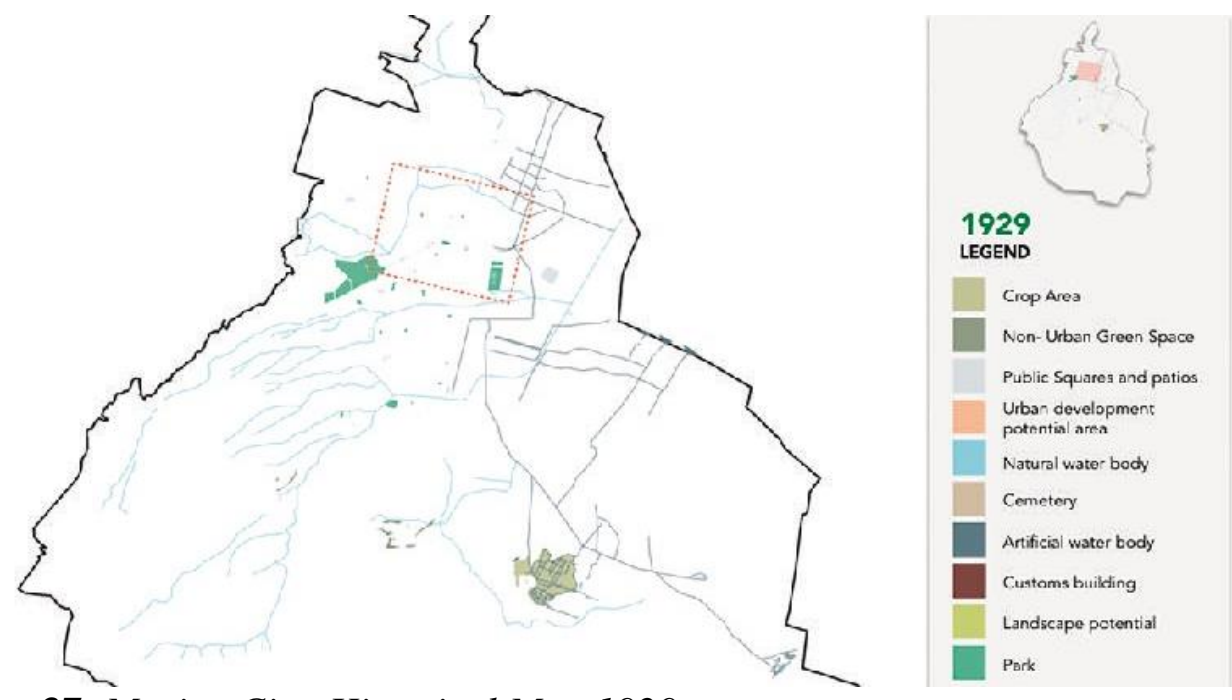

Figure 37. Mexico City, Historical Map 1929

Source: Produced by Jocelyn Urióstegui and Melissa Quintero. 
1943 - Presence of natural and artificial water bodies is still found, mostly on the outskirts of the historic limit, although some streams have been channeled to make way for streets. Urban growth continues South and West. Valuable open space to the West has been preserved as a national park (see Figure 38).

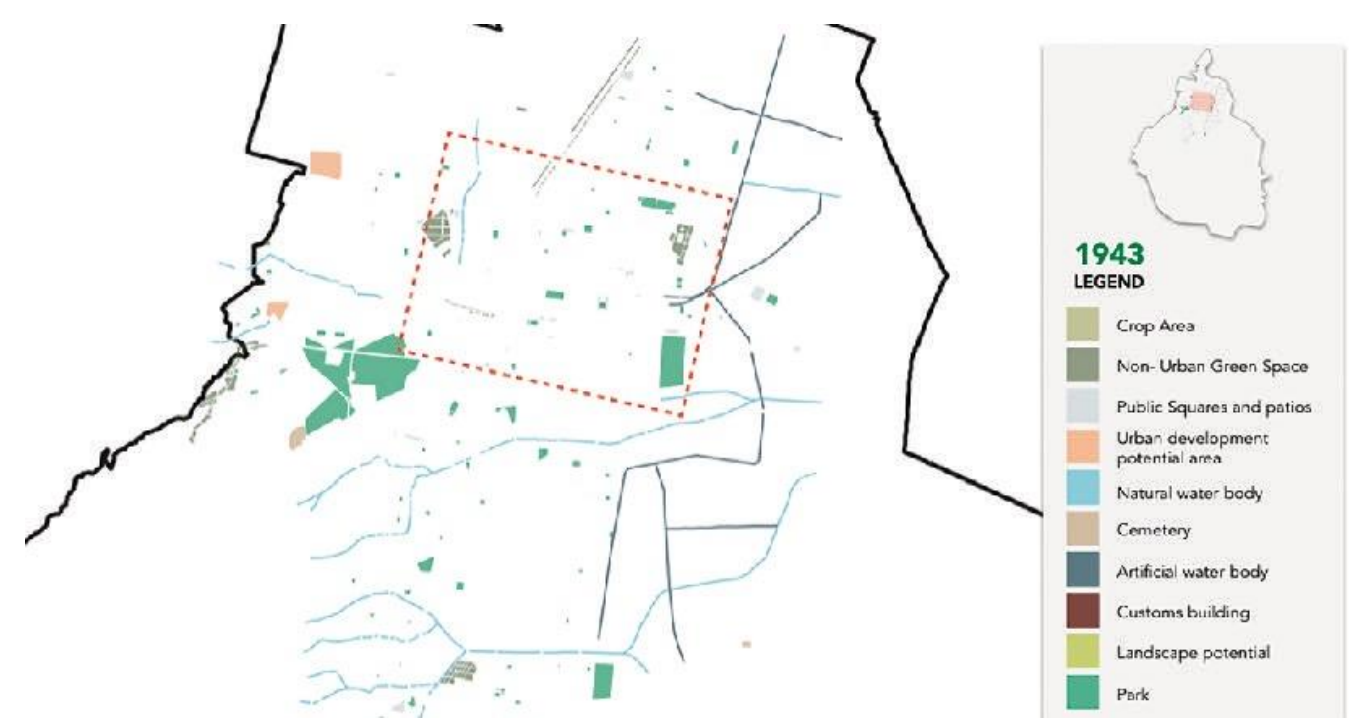

Figure 38. Mexico City, Historical Map 1943

Source: Produced by Jocelyn Urióstegui and Melissa Quintero.

1980 - Presence of other green spaces with landscape potential is found. Growth is shown towards the North of the historic city centre. Small towns to the East and West are still not connurbated. There are more parks and the famous Chapultepec Woodland Park shows an increase in territory. The city continues to grow concentrically away from the historic centre. For the purpose of this study, students focused on the southwest section of the urbanised area, including a small part of the bordering State of Mexico, for their project (see Figure 39).
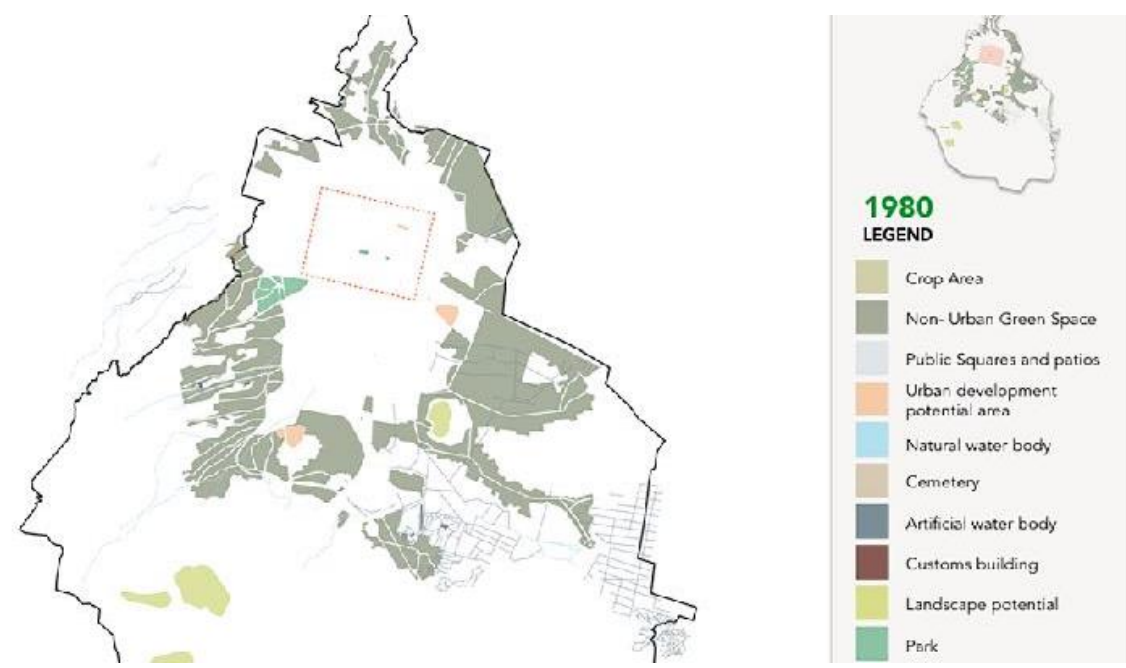

Figure 39. Mexico City, Historical Map 1980.

Source: Produced by Jocelyn Urióstegui and Melissa Quintero. 
2006 - The city has grown along the ravines and around the national park. No water bodies are appreciated as more bodies of water have been dried up and streams have been channeled. The city shows more parks than previous decades. To the West of the urbanised area there is landscape potential in the form of open space across state boundary lines (see Figure 40).

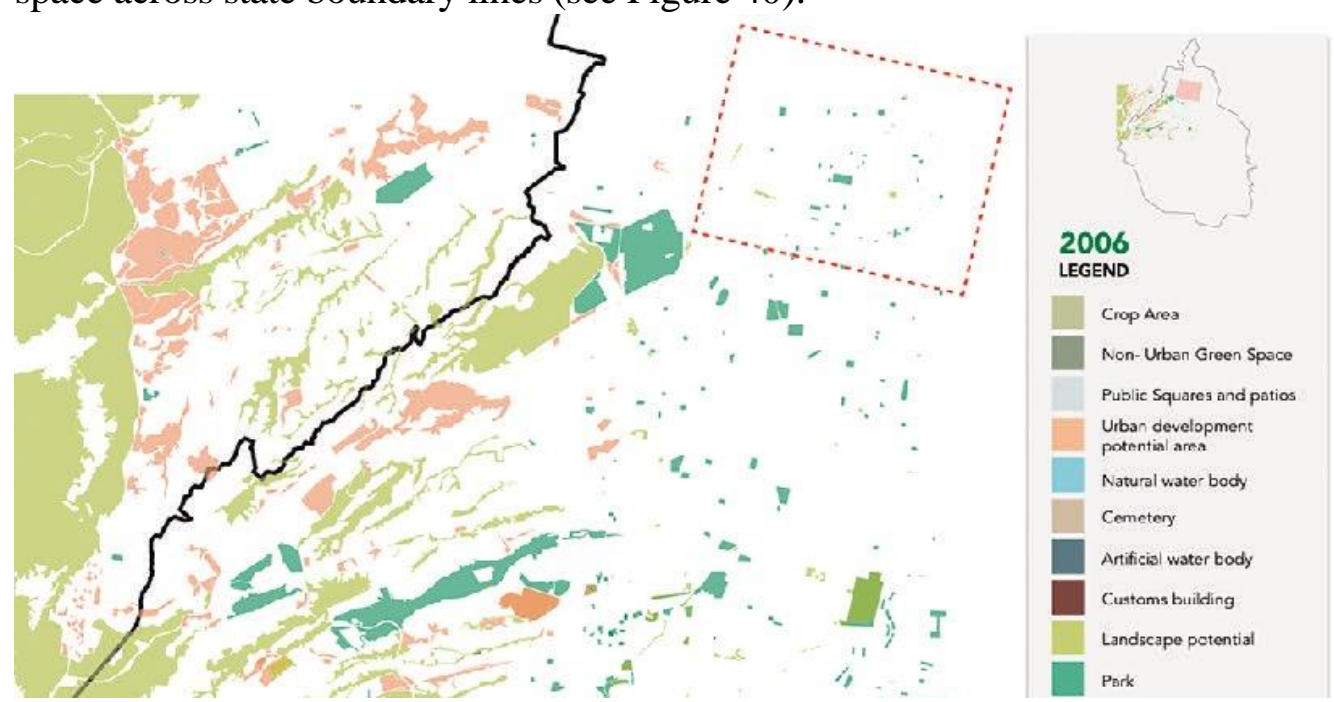

Figure 40. Mexico City, Historical Map 2006.

Source: Produced by Jocelyn Urióstegui and Melissa Quintero.

2018 - The amount of parks is slightly reduced. No more water bodies are appreciated, except for the presence of non-urbanised ravines that carry water during the rainy season. The amount of open space with landscape potential remains the same, compared with 2006 (see Figure 41).

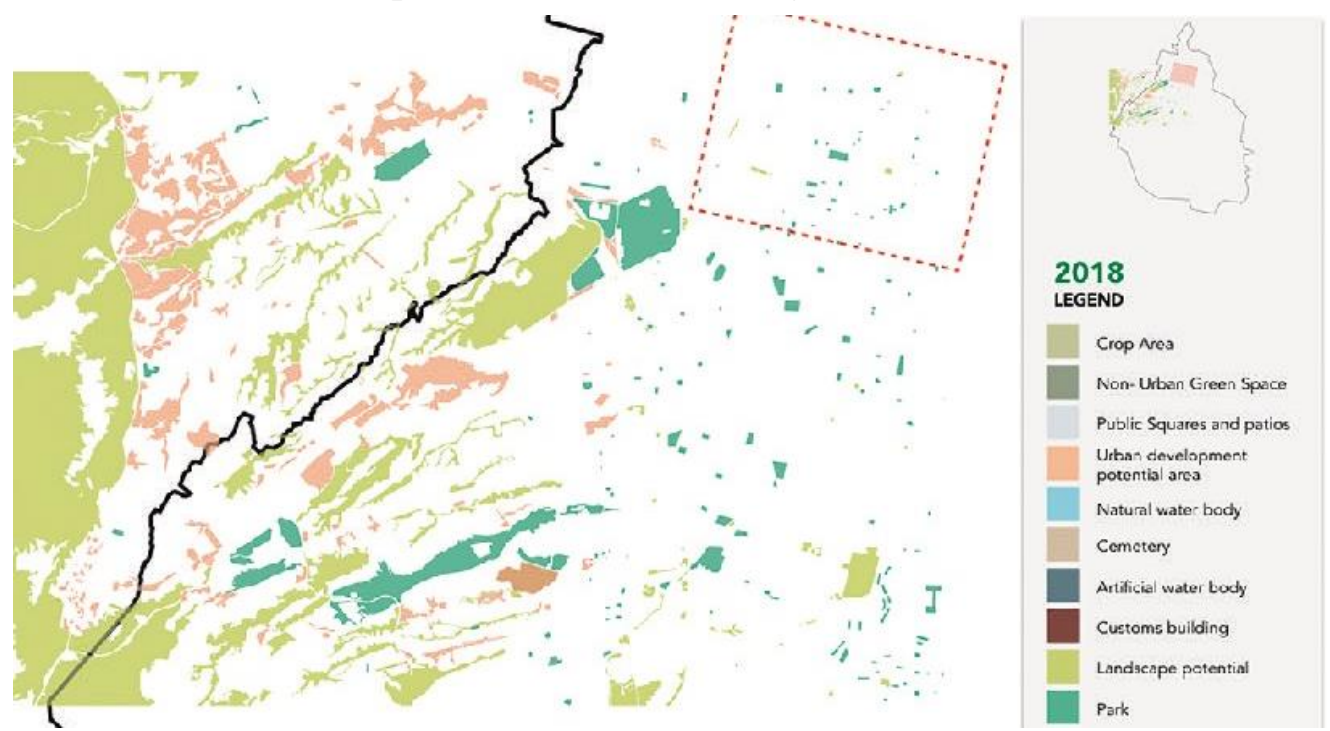

Figure 41. Mexico City, Historical Map 2018

Source: Produced by Jocelyn Urióstegui and Melissa Quintero. 
Propose

Goals and Expectations of the Exercise: Park System/Project Proposal

All classmates work alone or in pairs. The study area is subdivided into 9 sections which are distributed among the different teams. Then together they assemble these into a mosaic. Once assembled, the connections between sections is 'tweaked' and agreed upon by the different students.

The strategy used to assemble the Park System emerges from the research on historical examples mentioned above, and resulting in the following criteria:

1. Place potential landmarks (old trails, old infrastructure) onto the Google Maps Pro latest version.

2. Connect the existing and potential green areas contained within each sector.

3. Park Typologies to be considered:
a. National parks and reserves
b. Metropolitan parks
c. Neighbourhood parks
d. Green squares
e. Cemeteries
f. Cloisters and convent patios
g. Archaeological sites
h. Unbuilt urban block cores

4. Historical Systems (old infrastructures, aqueducts, canals, bridges)

5. Connectors:

a. Trails, rivers and streams, ravines

b. Streets, avenues, boulevards

c. Rights of way, medians, sidewalks

6. Landmarks (existing public services, monuments, roundabouts)

7. Landscape (private gardens, golf courses, sports clubs, vertical gardens, rooftop gardens, terraces, balconies)

All classmates work together in order to finalise the proposal for the entire 'mosaic', creating a Park System in the selected area of Mexico City.

Examples and Findings: Case Study

In Mexico City, the abovementioned conditions can be utilised as part of the park system strategy, but other conditions must also prevail. The 9 sectors mentioned in the Mexico City exercise were subdivided into three geographically differentiated areas. The easternmost sectors were located on the ancient lake bed, and enclosed the historic centre, as well as the most urbanised and densely 
populated section. The middle sectors were located in the transition area (between the lake bed and the foot of the hills), enclosing an urbanised area on difficult ground, especially due to the presence of ravines and ancient streams (now mostly channeled) that nurtured the lakes. This section is also urbanised. The westernmost sectors were located in the semi-urbanised area, enclosing connurbated old villages, high-end urban extensions, surrounding preserved natural areas and some informal settlements. Most formal urban parks are in the eastern and middle section. The western section has less formal urban parks, but contains one of the city's national parks (see Figure 42).

When juxtaposing socio-economic information from the Mexican National Institute of Statistics and Geography (INEGI), onto the Google Maps exercise of mapping the green areas, lower income areas resulted with much less formal parks and green squares than the higher income neighbourhoods (see Figure 43). The strategy, therefore, for the proposal was:

a. to connect the existing different scale parks through tree-lining streets and avenues (see Figure 44);

b. to consider the cemeteries as part of the park system (see Figure 44);

c. to consider private clubs, golf courses, private gardens as 'landscape' in beautifying the road network and contributing to 'connect' (see Figure 45);

d. to use the 'borders' between different economic level neighbourhoods as 'suturing connectors', in order to distribute the value of green landscape and improve the areas between these levels (see Figure 43);

e. to find park area potential in the low-income areas, through detecting vacant lots, underused land under road bridges (see Figure 46);

$\mathrm{f}$. to use the ravines as linear promenade-parks and 'binding' areas between neighbourhoods (see Figure 46);

g. to use the primary east-west avenues as 'bridges' between the three geographic sectors (see Figure 47 and Figure 48).

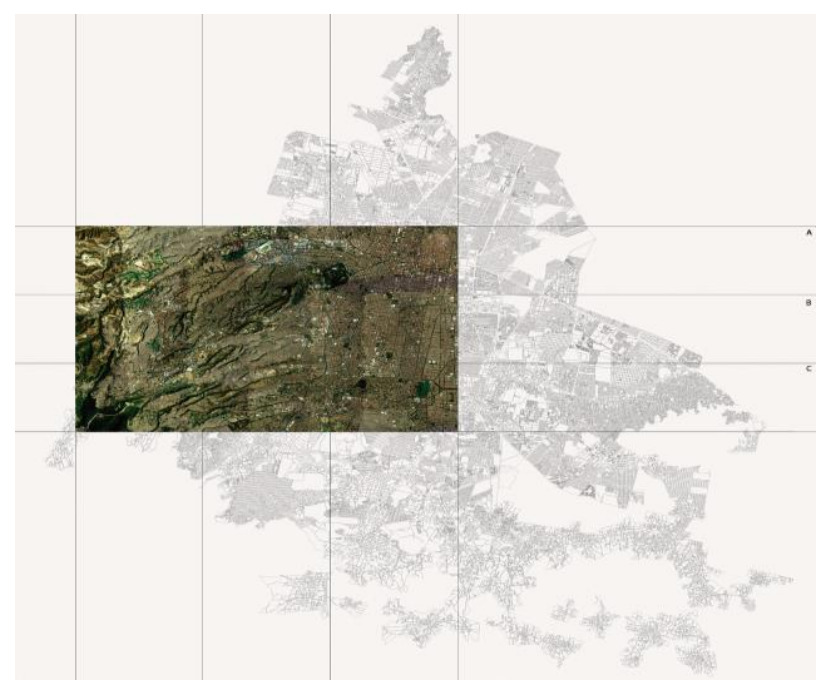

Figure 42. Selected Study Case Area

Source: Produced by Roxana Hernández and Fernando Gómez 2019. 


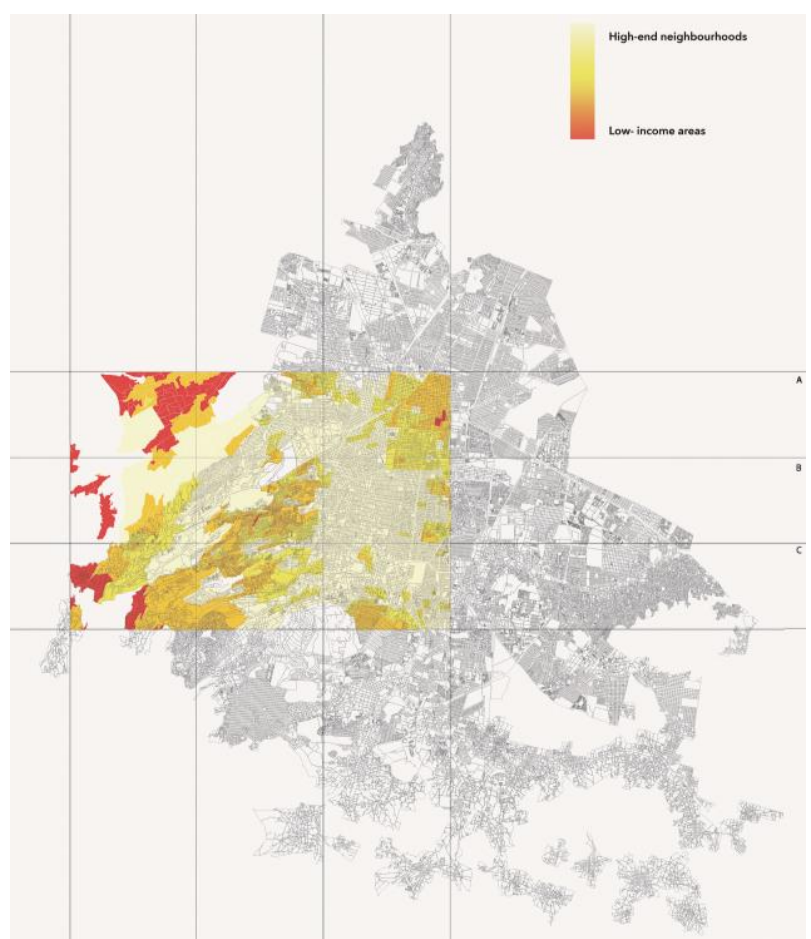

Figure 43. Socio-Economic Information

Source: Produced by Roxana Hernández and Fernando Gómez 2019.

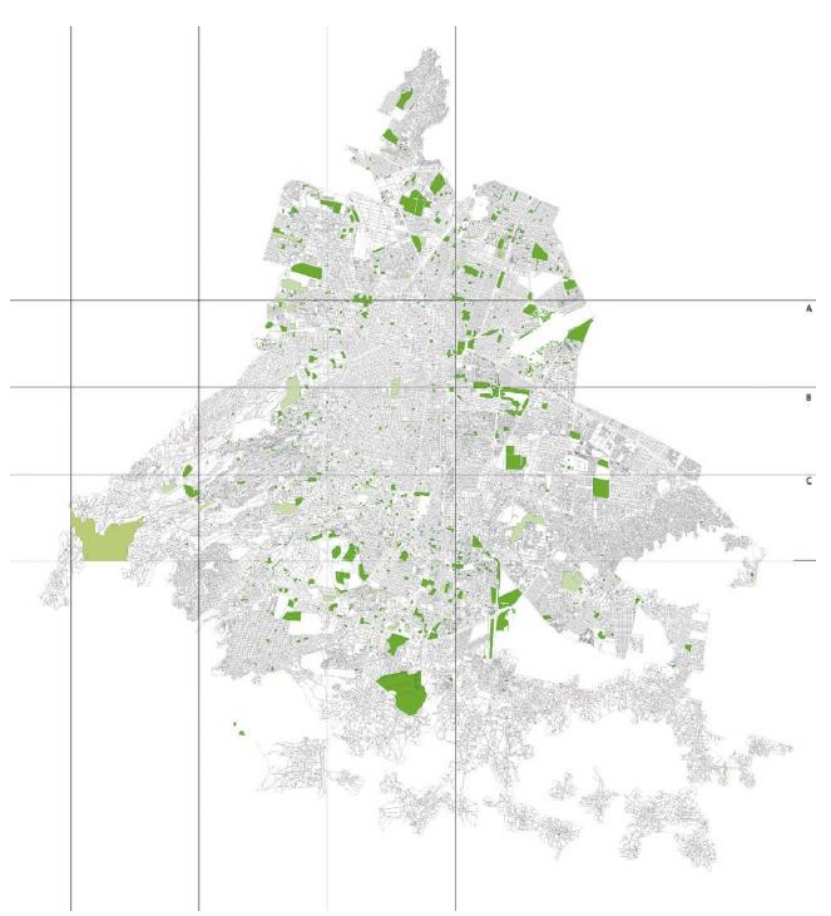

Figure 44. Classification of Existing Parks by Scale and Function Source: Produced by Roxana Hernández and Fernando Gómez 2019. 


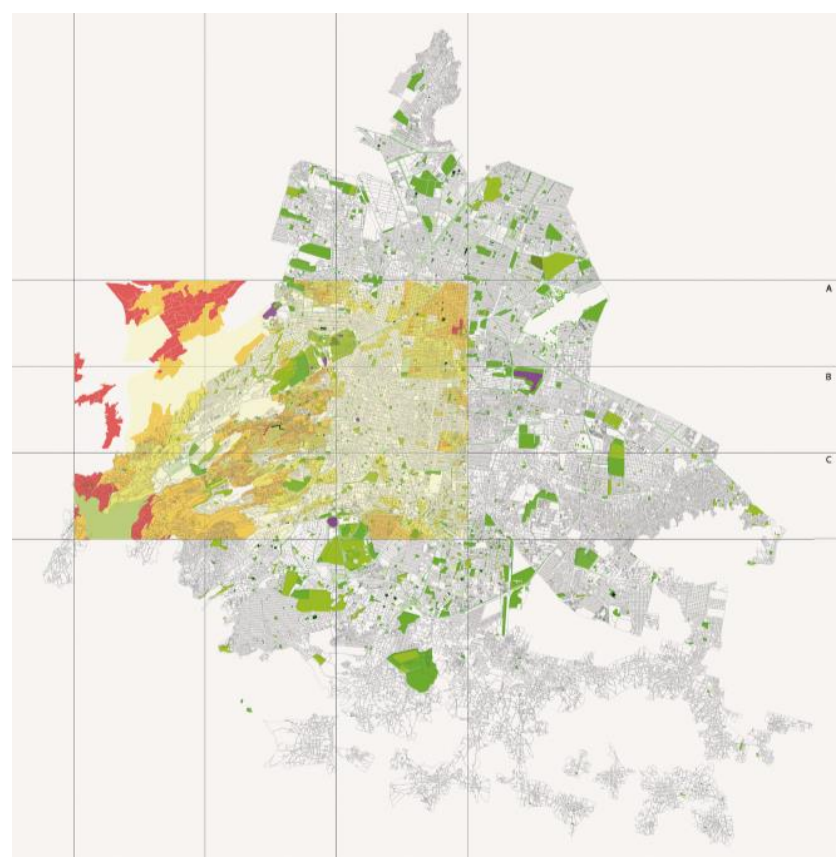

Figure 45. Private Clubs and Gardens, Golf Courses, to be Used for Scenic Potential

Source: Produced by Roxana Hernández and Fernando Gómez 2019.

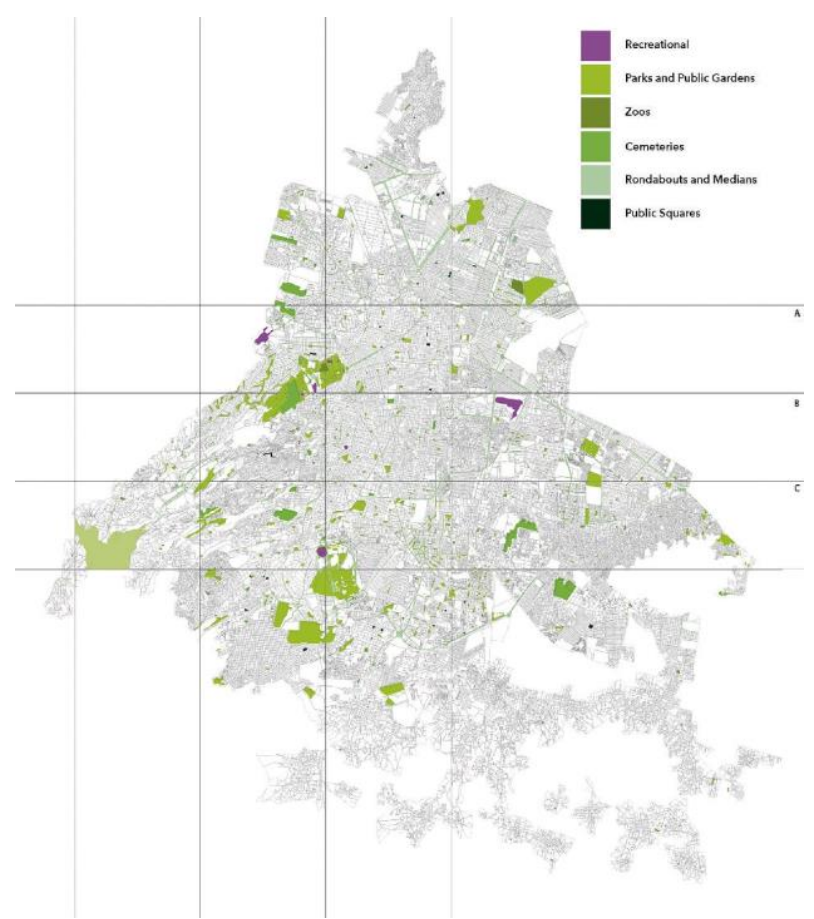

Figure 46. Colours Ranging from Light Yellow to Dark Red Show the Corresponding Level of Income from High to Low. This Map Shows the Amount of Parks in Affluent Neighbourhoods as Opposed to Poor Ones

Source: Produced by Roxana Hernández and Fernando Gómez 2019. 


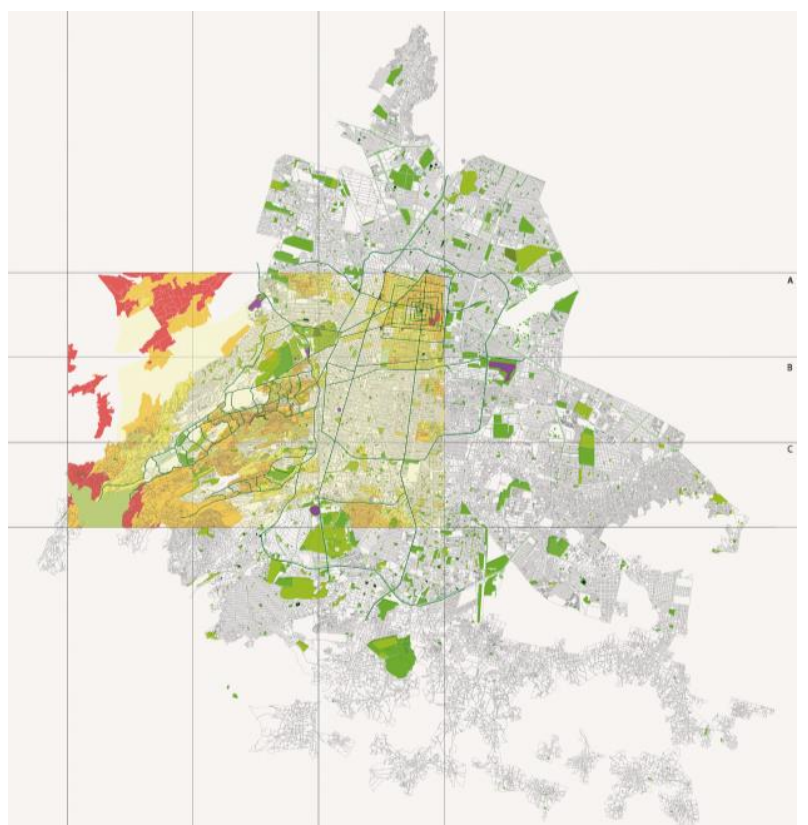

Figure 47. Project Proposal Showing Existing and Projected Parks with Corresponding Connector-Avenues

Source: Produced by Roxana Hernández and Fernando Gómez 2019.

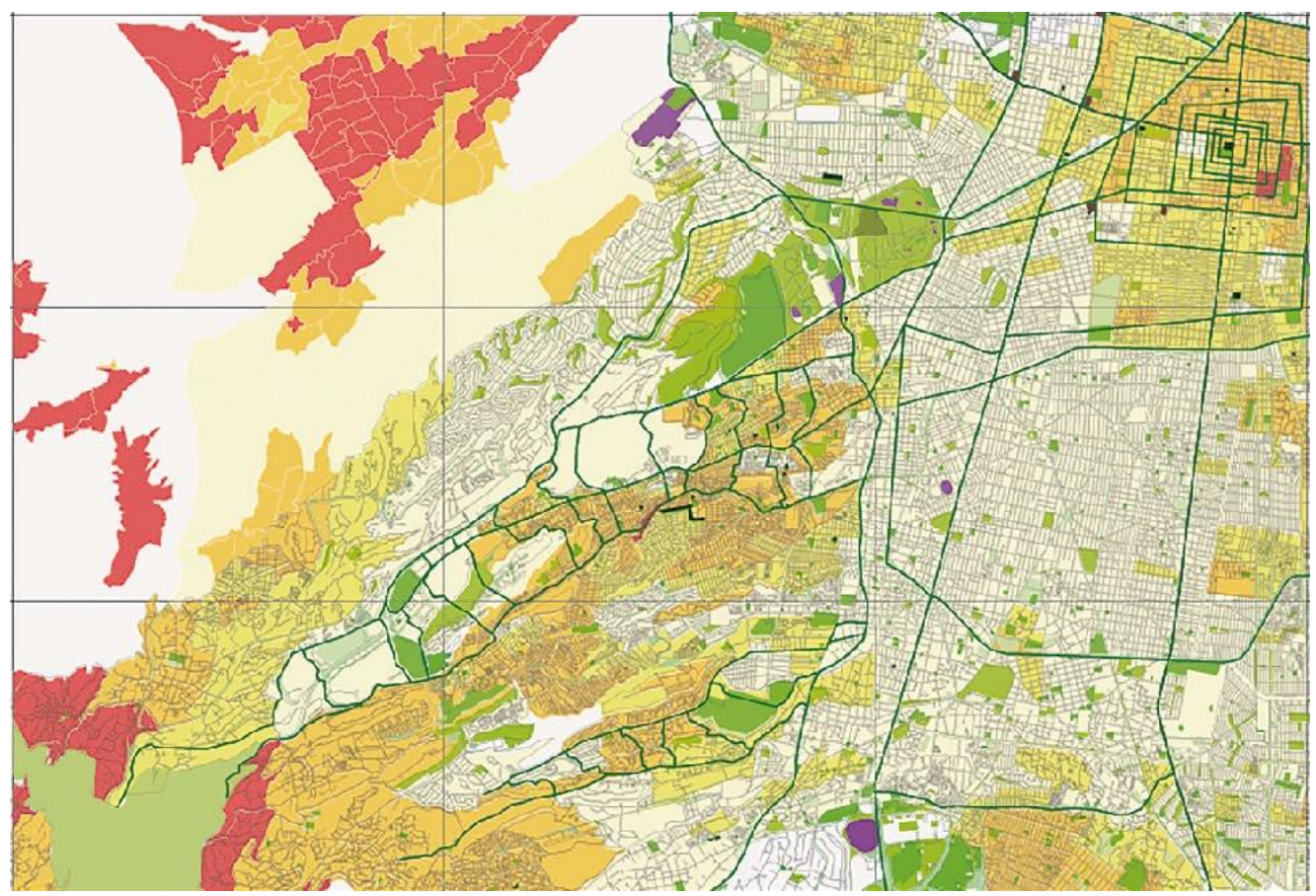

Figure 48. Project Proposal, Zoom-in of the Selected Case Study Area, Showing Existing and New Parks Connected by Reforested Streets and Avenues Source: Elaborated by Roxana Hernández and Fernando Gómez 2019. 


\section{Conclusions}

A park system does not have to be designed from scratch. It can be incorporated into an already existing, and even historical, urban form. It is a method of exploring and finding the potential of open space in the city, beginning with the careful exploration of up-to-date maps and using the geographical Information tools.

As Tom Turner has stated, "Designing towns and gardens involves the layout of enclosed outdoor space. Sixteenth-century Isfahan, seventeenthcentury Paris, eighteenth-century London, nineteenth-century Washington, D.C and the Garden Cities of the twentieth century were composed like gardens, to their immense benefit." 33

In the case of Mexico City, thinking about social cohesion was a key criterion. Parks should work as stitches that join neighbourhoods in unfavorable conditions and privileged populations, in an attempt to blur the boundaries between different socio-economic levels. In our view, this is an innovative 'suturing' strategy, to bind together neighbourhoods, create community and structure the city by building identity.

A term with students exploring these possibilities enables them to acquire knowledge, skills and awareness of the possibilities of open space design and how this can impact their future professional outlook on the environment.

\section{Acknowledgments}

I would like to thank my Research Assistant Maite García Vedrenne, whose invaluable help with the graphics of this presentation, but mostly through her help during my teaching assignments and her contribution to the synthesis of our work together with students, which has given fruit to a continuing learning experience and this article. I also would like to thank my students and interns Melissa Quintero, Roxana Hernández, Jocelyn Urióstegui and Fernando Gómez, who not only carried out their assigned homework with excellence, but also put together the overall Park System Project for a section of Mexico City. I have also included the work of other students from the Fall 2018 and Spring 2019 terms of the undergraduate Architecture course. Special thanks to Marion González Busto for her insight and putting this into protocol format.

\section{Bibliography}

Aguilar-Dubose, C. El Parque Urbano: Entre Naturaleza y Democracia. [The Urban Park: Between Nature and Democracy.] Ciudad de México: Universidad Iberoamericana, 2020. [En revisión para su publicación].

America's National Trails System. National Trails System. Retrieved from: https://www. nps.gov/subjects/nationaltrailssystem/index.htm. [Accessed June, 2019].

33. Turner, Garden History: Philosophy and Design 2000 BC-2000 AD, 2005, 3. 
Bacon, E. N. Design of Cities. New York: Penguin Books, 1976.

Beveridge, C. E. and P. Rocheleau. Frederick Law Olmsted: Designing the American Landscape. New York: Rizzoli International Publications, Inc., 1995.

Boesiger, W. Le Corbusier. London: Thames and Hudson, Ltd., 1972.

Brown, L. J., D. Dixon and O. Gillham. Urban Design for an Urban Century: Placemaking for People. New Jersey: John Wiley \& Sons, Inc., 2009.

Duany, A., E. Plater-Zyberk and R. Alminana. The New Civic Art: Elements of Town Planning. New York: Rizzoli International Publications, Inc., 2003.

Eguiarte, E. "La Ciudad Pensada: Una Ciudad que no Fue. México 1900-1911." [The Thought City: a City that was not. Mexico 1900-1911.] In Revista Arquitectónica, no. 6. Edited by Gigliola Carozzi. Ciudad de México: University Iberoamericana, Otoño, 2004.

Estevan, A. La Ciudad que Perdió su Río. [The City that Lost its River.] El País, 2006. Retrieved from: https://bit.ly/30asz4c.

Farr, D. Sustainable Urbanism: Urban Design with Nature. New Jersey: John Wiley \& Sons, Inc., 2008.

Forestier, J. C. N. Grandes Villes et Systèmes de Parcs: Suivi de Deux Mémoires sur les Villes Impériales du Maroc et sur Buenos Aires. [Large Cities and Park Systems: Followed by Two Papers on the Imperial Cities of Morocco and on Buenos Aires.] Paris: Editions Norma, 1997.

Gruppo '2C'. "Cerdà's Barcelona. The Elements of Ensanche and Construction of the Block." LOTUS International, no. 23. New York: Rizzoli International Publications, Inc., 1979.

Hall, P. Cities of Tomorrow: An Intellectual History of Urban Planning and Design since 1880. Oxford: Blackwell Publishers, 1996.

Ingold, T. The Temporality of Landscape. Contemporary Archaeology in Theory: The New Pragmatism. $2^{\text {nd }}$ Edition. Edited by R. W. Preucel, S. A. Mrozowski. Blackwell Publishers Ltd, 2010.

Jordan, D. P. Transforming Paris: The Life and Labors of Baron Haussmann. New York: The Free Press, Simon and Schuster, Inc., 1995.

Lupton, E. Design is Storytelling. New York: Cooper Hewitt, Smithsonian Design Museum, 2017.

Martí-Ciriquián, P. and C. García-Mayor. "Waterfronts in Spanish Cities: New Urban Spaces." Bitácora Urbano Territorial 28, no. 3 (2018).

Moore, C. (Ed.) Plan of Chicago. Centennial Edition. Edited by D. H. Burnham and E. H. Bennett. Chicago: The Great Books Foundation, 2009.

Morris, A. E. J. History of Urban Form Before the Industrial Revolution. London: George Godwin Limited, 1979.

Panerai, P., J. Castex and J.-C. Depaule. Formes Urbaines: De l'îlot à la Barre. [Urban Forms: From the Block to the Barre.] Marseille: Éditions Parenthèses, 2001.

Parque México. [Park Mexico.] Wikipedia, la Enciclopedia Libre. Retrieved from: https://es.wikipedia.org/wiki/Parque_M\%C3\%A9xico. [Accessed June, 2019].

Tate, A. Great City Parks. New York: SPON Press, 2004.

Turner, T. City as Landscape: A Post-Postmodern View of Design and Planning. London: E \& FN Spon, 1996.

Turner, T. Garden History: Philosophy and Design 2000 BC-2000 AD. New York: SPON Press, Taylor \& Francis Group, 2005. 